\title{
MXenes for Solar Cells
}

Check for

updates

Cite as

Nano-Micro Lett.

(2021) 13:78

Received: 16 November 2020

Accepted: 5 January 2021

Published online: 21 February 2021

(C) The Author(s) 2021

\author{
Lujie Yin ${ }^{1}$, Yingtao $\mathrm{Li}^{1}$, Xincheng Yao ${ }^{1}$, Yanzhou Wang ${ }^{1}$, Lin Jia ${ }^{1}$, Qiming Liu ${ }^{1}$, \\ Junshuai $\mathrm{Li}^{1}{ }^{\square}$, Yali $\mathrm{Li}^{1}{ }^{\natural}$, Deyan $\mathrm{He}^{1}$
}

\section{HIGHLIGHTS}

- This review summarizes applications and developments of MXenes in solar cells by far.

- The issues needing to be addressed for performance improvement of the related solar cells are discussed.

- Suggestions are given for pushing exploration of MXenes' application in solar cells.

\begin{abstract}
Application of two-dimensional MXene materials in photovoltaics has attracted increasing attention since the first report in 2018 due to their metallic electrical conductivity, high carrier mobility, excellent transparency, tunable work function and superior mechanical property. In this review, all developments and applications of the $\mathrm{Ti}_{3} \mathrm{C}_{2} \mathrm{~T}_{x}$ MXene (here, it is noteworthy that there are still no reports on other MXenes' application in photovoltaics by far) as additive, electrode and hole/electron transport layer in solar cells are detailedly summarized, and meanwhile, the problems existing in the related studies are also discussed. In view of these problems, some suggestions are given for pushing exploration of the MXenes' application in solar cells. It is believed that this review can provide a comprehensive and deep understanding into the research status and, moreover, helps widen a new situation for the study of MXenes in photovoltaics.
\end{abstract}

KEYWORDS $\mathrm{Ti}_{3} \mathrm{C}_{2} \mathrm{~T}_{x}$ MXene; Solar cells; Additives; Hole/electron transport layers; Electrodes

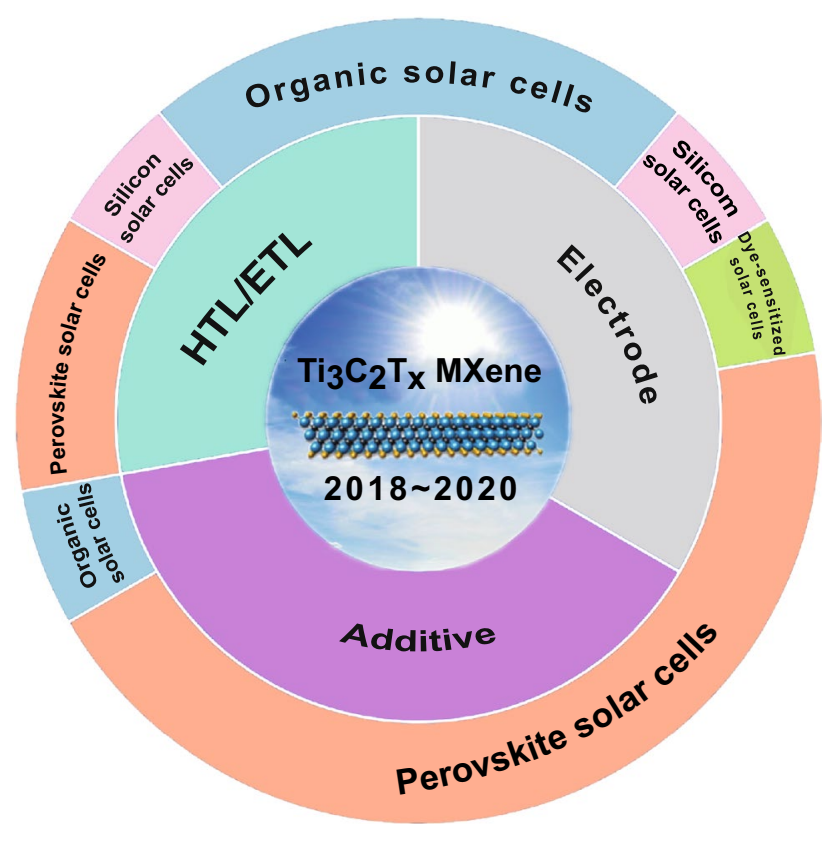

$\checkmark$ Junshuai Li, jshli@1zu.edu.cn; Yali Li, liyli@lzu.edu.cn

1 Key Laboratory of Special Function Materials and Structure Design of the Ministry of Education, and School of Physical Science and Technology, Lanzhou University, 222 South Tianshui Road, Lanzhou 730000, People's Republic of China 


\section{Introduction}

With the ever-increasing demand of clean and renewable energy resources [1-4], considerable attention has been devoted to the development of novel materials toward efficient solar cells [5-14]. As a family of important two-dimensional materials, MXenes, layered carbides and nitrides of transition metals first reported by the Gogotsi group in 2011 [15], which have been extensively investigated in various fields including energy storage [16-22], biomedical fields [23-25], electromagnetic applications [26-29], sensors [30-34], light-emitting diodes [35-37], water purification [38-43] and catalysis [44-47], have exhibited promising application in solar cells very recently. Among various MXenes, $\mathrm{Ti}_{3} \mathrm{C}_{2} \mathrm{~T}_{x}$ ( $\mathrm{T}$ represents some surface-terminating functional groups such as $-\mathrm{O},-\mathrm{OH}$ and $-\mathrm{F}$ ) dominates the present study of MXenes in solar cells because of its high electrical conductivity and carrier mobility, excellent transparency and tunable work function (WF) [48-50]. Since the first report of $\mathrm{Ti}_{3} \mathrm{C}_{2} \mathrm{~T}_{x}$ as an additive in the photoactive layer of $\mathrm{MAPbI}_{3}\left(\mathrm{MA}: \mathrm{CH}_{3} \mathrm{NH}_{3}\right.$ )-based perovskite solar cells (PSCs) in 2018 [51], its application has been extended to electrode, hole/electron transport layer (HTL/ETL), additive in HTL/ETL and the component of forming the Schottky junction-based solar cells with silicon ( $\mathrm{Si}$ ) wafers, etc.

To comprehensively understand the achievements and meanwhile to provide insights and valuable suggestions for the following development, a timely summary and discussion of the related studies is highly necessary. In this review, we first categorize the roles of $\mathrm{Ti}_{3} \mathrm{C}_{2} \mathrm{~T}_{x}$ played in the reported solar cells and then follow the roles to introduce the achievements and analyze the existing problems limiting device performance improvement. Finally, a perspective to outlook the further development of the MXenes' application in solar cells is given.

As summarized in Fig. 1, the roles of the $\mathrm{Ti}_{3} \mathrm{C}_{2} \mathrm{~T}_{x}$ MXene in application of solar cells can be categorized into three kinds, i.e., additive [51], electrode [52] and HTL/ETL [53]. In the meantime, the corresponding type of the solar cells is also summarized for each role played by $\mathrm{Ti}_{3} \mathrm{C}_{2} \mathrm{~T}_{x}$. Moreover, it is noted that the corresponding areas of the roles and the solar cells in Fig. 1 are in direct proportion to the number of the reports/publications. One thus can conclude that the $\mathrm{Ti}_{3} \mathrm{C}_{2} \mathrm{~T}_{x}$ MXene is mainly applied in perovskite and organic solar cells (OSCs). In the following part, the review will be extended following the role of the $\mathrm{Ti}_{3} \mathrm{C}_{2} \mathrm{~T}_{x}$ MXene.

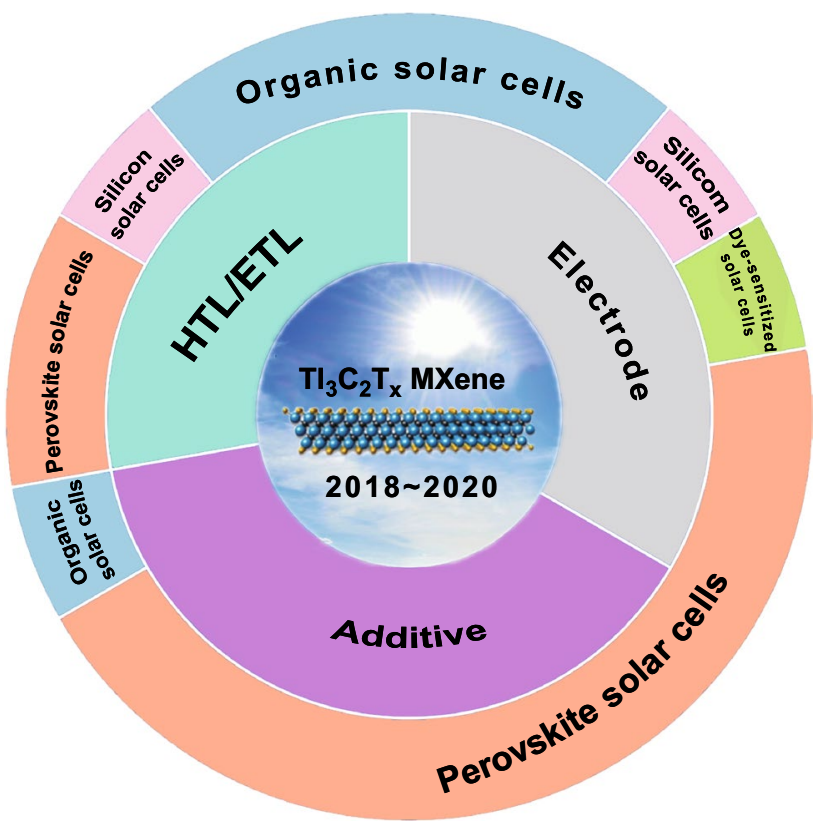

Fig. 1 Roles of the $\mathrm{Ti}_{3} \mathrm{C}_{2} \mathrm{~T}_{x}$ MXene played in application of varying solar cells. The areas correspond to the publication numbers for each application

\section{Applications of MXenes in Solar Cells}

\subsection{Additive in Perovskite Materials, ETLs/HTLs}

In 2018, Guo et al. first reported addition of $\mathrm{Ti}_{3} \mathrm{C}_{2} \mathrm{~T}_{x}$ into the $\mathrm{MAPbI}_{3}$-based perovskite absorber [51], initiating exploration of the MXenes' application in solar cells. Their study indicates that addition of $\mathrm{Ti}_{3} \mathrm{C}_{2} \mathrm{~T}_{x}$ can retard the nucleation process of $\mathrm{MAPbI}_{3}$ (see the schematic diagram in Fig. 2a), resulting in the enlarged crystal size. Moreover, the $\mathrm{Ti}_{3} \mathrm{C}_{2} \mathrm{~T}_{x}$ additive is highly beneficial to accelerate the electron transfer, like a "carrier bridge" [54-57], through the grain boundary, which is further confirmed by the lower charge transfer resistance for the $\mathrm{Ti}_{3} \mathrm{C}_{2} \mathrm{~T}_{x}$-added device as indicated by the electrochemical impedance spectra exhibited in Fig. 2b. Thanks to these effects, the average power conversion efficiency (PCE) increases from $15.18 \%$ to $16.80 \%$. (Note: all PCEs in this review were measured at $\mathrm{AM} 1.5 \mathrm{G}$ illumination.)

In 2019, Agresti et al. reported the WF adjustment of the $\mathrm{MAPbI}_{3}$ films and thus optimization of the energy-level alignment for improving the performance of the related solar cells by adding the $\mathrm{Ti}_{3} \mathrm{C}_{2} \mathrm{~T}_{x}$ MXene [58]. It was found that the WF of the perovskite films could be effectively tuned from 4.72 to $4.37 \mathrm{eV}$ without affecting other intrinsic 
(a)

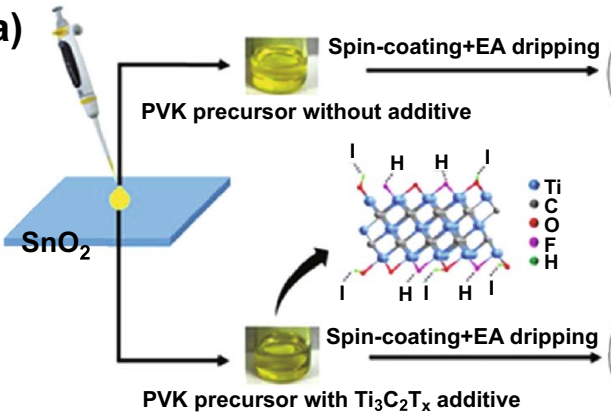

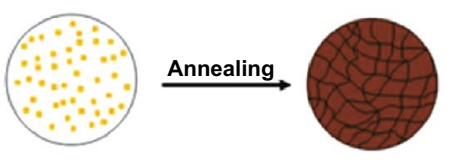

(b)

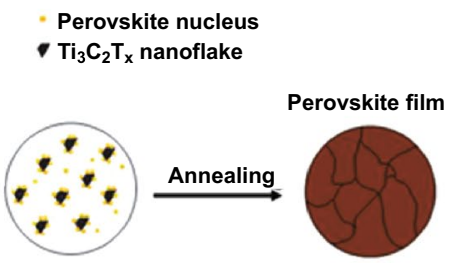

(c)

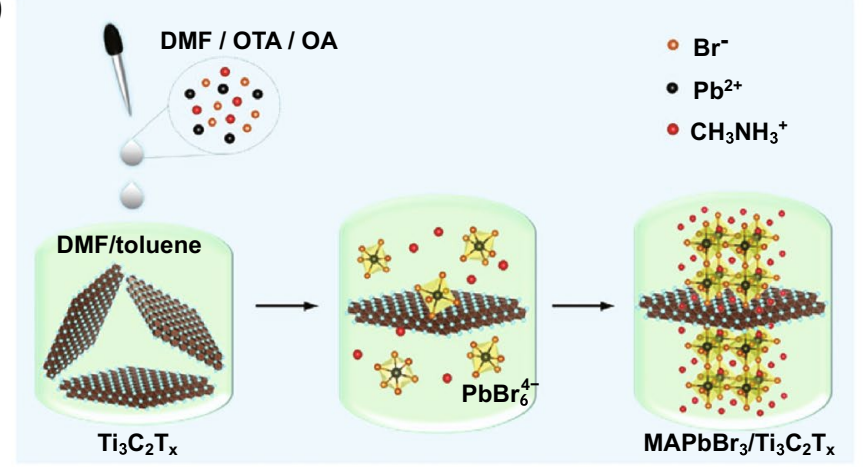

(e)

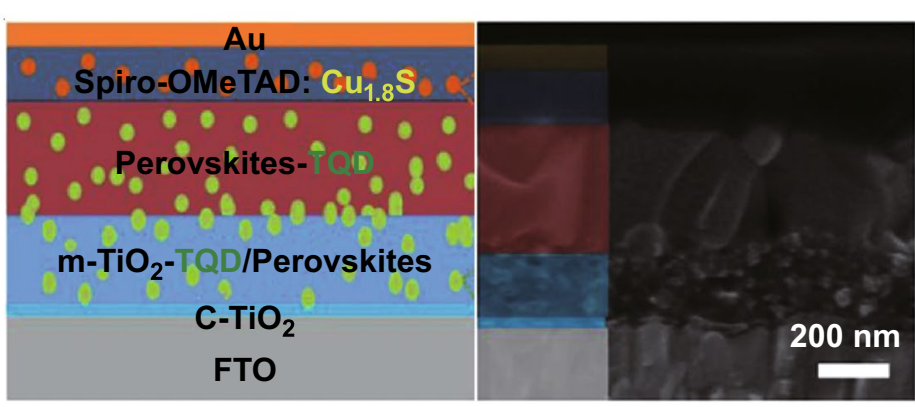

(f)

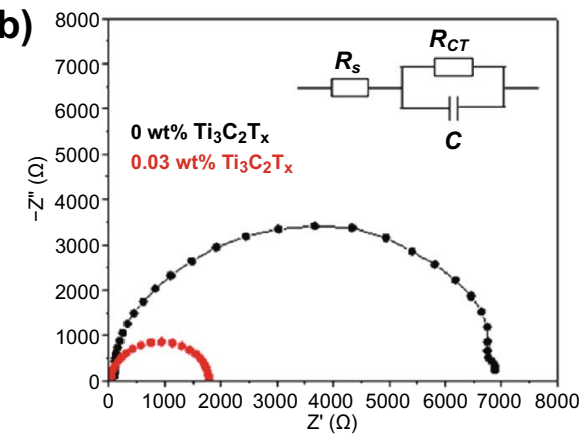

(d)
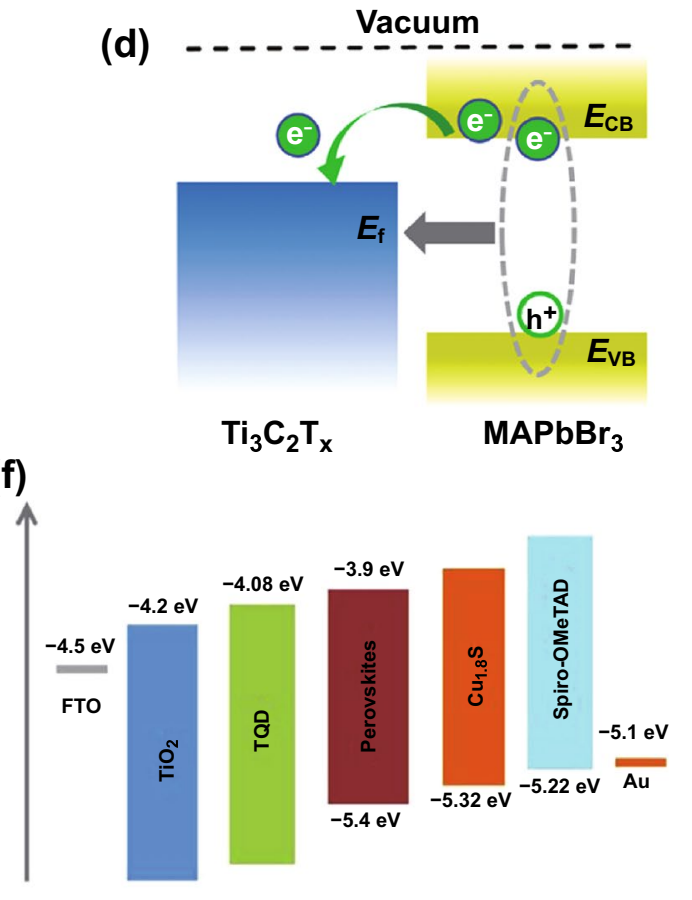

Fig. 2 a Nucleation and growth routes of the $\mathrm{MAPbI}_{3}$-based perovskite films with and without adding the $\mathrm{Ti}_{3} \mathrm{C}_{2} \mathrm{~T}_{x} \mathrm{MXene} \mathbf{b} \mathrm{Nyquist}$ plots of the PV devices with and without $0.03 \mathrm{wt} \% \mathrm{Ti}_{3} \mathrm{C}_{2} \mathrm{~T}_{x}$ addition measured in the dark with a bias of $0.7 \mathrm{~V}$. Copyright $\odot 2018 \mathrm{WILEY}-\mathrm{VCH}$ Verlag GmbH \& Co. KGaA, Weinheim. c Schematic illustration of the preparation process of surface-decorated $\mathrm{MAPbBr}_{3}$ nanocrystals by fewlayer $\mathrm{Ti}_{3} \mathrm{C}_{2} \mathrm{~T}_{x}$ MXene nanosheets, i.e., $\mathrm{MAPbBr}{ }_{3} / \mathrm{Ti}_{3} \mathrm{C}_{2} \mathrm{~T}_{x}$ heterostructures. d Energy-level alignment and electron transfer between the $\mathrm{MAPbBr}_{3}$ crystals and the coated $\mathrm{Ti}_{3} \mathrm{C}_{2} \mathrm{~T}_{x}$ nanosheets. Copyright (C) 2020 WILEY-VCH Verlag GmbH \& Co. KGaA, Weinheim. e Device architecture and cross-sectional scanning electron microscopy (SEM) image, and $\mathbf{f}$ energy-level alignment of the perovskite solar cell with the embedded ultrathin $\mathrm{Ti}_{3} \mathrm{C}_{2} \mathrm{~T}_{x}$ quantum dots in the perovskite layer and the $\mathrm{ETL} / \mathrm{TiO}_{2}$ interface and $\mathrm{Cu}_{1.8} \mathrm{~S}$ in the Spiro-OMeTAD HTL. Copyright $\odot 2020$ WILEY-VCH Verlag GmbH \& Co. KGaA, Weinheim

electronic properties such as bandgap, the relative position of the valance band to the Fermi level and film morphology. The PCE of the $\mathrm{Ti}_{3} \mathrm{C}_{2} \mathrm{~T}_{x}$-incorporated $\mathrm{MAPbI}_{3}$-based solar cells can be improved by $26.5 \%$ after simultaneously introducing $\mathrm{Ti}_{3} \mathrm{C}_{2} \mathrm{~T}_{x}$ addition in the ETL, as compared to the control one without $\mathrm{Ti}_{3} \mathrm{C}_{2} \mathrm{~T}_{x}$. Recently, Zhang et al. reported surface decoration of $\mathrm{MAPbBr}_{3}$ nanocrystals by few-layer $\mathrm{Ti}_{3} \mathrm{C}_{2} \mathrm{~T}_{x}$ MXene nanosheets to form the perovskite/ MXene heterostructure via in situ solution growth, as shown in Fig. 2c [59]. The facilitated electron injection from the MAPbBr ${ }_{3}$ nanocrystals to the $\mathrm{Ti}_{3} \mathrm{C}_{2} \mathrm{~T}_{x}$ MXene because of the matched energy levels, as indicated in Fig. 2d, is beneficial to performance improvement for the related solar cells.

Very recently, Chen et al. first reported employment of ultrathin $\mathrm{Ti}_{3} \mathrm{C}_{2} \mathrm{~T}_{x}$ quantum dots (TQDs) to engineer the CsFAMA (FA: $\mathrm{CH}\left(\mathrm{NH}_{2}\right)_{2}$ ) perovskite absorber and the perovskite $/ \mathrm{TiO}_{2}$ ETL interface, as indicated in Fig. 2e [60]. Thanks to the improved crystallinity of the perovskite 
film and the matched energy-level alignment (Fig. 2f) and thus the enhanced electron extraction at the perovskite/ $\mathrm{TiO}_{2}$ ETL interface, the solar cell delivers a remarkable hysteresis-free PCE of $20.72 \%$ compared with $18.31 \%$ for the reference device and long-time ambient and light stability. It is notable that the improved performance and stability are also partly contributed by the addition of $\mathrm{Cu}_{1.8} \mathrm{~S}$ in the HTL facilitating the perovskite crystallinity and the increased hole extraction at the perovskite/SpiroOMeTAD HTL interface because of the matched energylevel alignment, as indicated in Fig. 2f.

Besides addition in the active layer, embedding the $\mathrm{Ti}_{3} \mathrm{C}_{2} \mathrm{~T}_{x}$ MXene in ETLs/HTLs has also been reported. In 2019, Yang et al. reported modification of the $\mathrm{SnO}_{2}$ ETL by adding $1.0 \mathrm{wt} \% \circ \mathrm{Ti}_{3} \mathrm{C}_{2} \mathrm{~T}_{x}$ for the $\mathrm{MAPbI}_{3}$-based PSCs (Fig. 3a, b for the schematized architecture and cross-sectional SEM image of the device). Thanks to the facilitated electron transport and enhanced hole blocking because of the optimized energy-level alignment due to $\mathrm{Ti}_{3} \mathrm{C}_{2} \mathrm{~T}_{x}$ addition (Fig. 3c), PCE increases to $18.34 \%$ from $17.23 \%$ for the control device without $\mathrm{Ti}_{3} \mathrm{C}_{2} \mathrm{~T}_{x}$ addition [61]. Huang et al. further advanced the $\mathrm{Ti}_{3} \mathrm{C}_{2} \mathrm{~T}_{x}$ MXene-added $\mathrm{SnO}_{2}$ ETL by introducing $\mathrm{TiO}_{2}$ with a suitable crystal phase for forming an effective heterojunction structure, named a multi-dimensional conductive network (MDCN) structure, as exhibited in Fig. 3d, e. Owing to the matched energy-level alignment (Fig. 3f) of the ETL with the $\left(\mathrm{FAPbI}_{3}\right)_{0.97}\left(\mathrm{MAPbBr}_{3}\right)_{0.03}$ photoactive and FTO transparent conductive layers, a PCE increment from $16.83 \%\left(\mathrm{SnO}_{2} \mathrm{ETL}\right)$ to $19.14 \%$ is achieved. Moreover, the MDCN-incorporated device exhibits high toleration to moisture and maintains $\sim 85 \%$ of the initial performance for more than 45 days in $30-40 \%$ humidity air due to an oxygen vacancy scramble effect [62].

Besides modification of the $\mathrm{MAPbI}_{3}$ photoactive layer using $\mathrm{Ti}_{3} \mathrm{C}_{2} \mathrm{~T}_{x}$, Agresti et al. also incorporated $\mathrm{Ti}_{3} \mathrm{C}_{2} \mathrm{~T}_{x}$ into the $\mathrm{TiO}_{2} \mathrm{ETL}$ to finely tune its WF, i.e., from 3.91 to $3.85 \mathrm{eV}$ that benefits for tuning the interface energy-level alignment between the perovskite absorber and the $\mathrm{TiO}_{2} \mathrm{ETL}$, thus reducing the barrier height and enhancing charge transfer [58]. Based on dual addition and optimization in both the $\mathrm{MAPbI}_{3}$ photoactive and $\mathrm{TiO}_{2}$ electron transport layers, the device delivers a PCE of $20.14 \%, \sim 26.5 \%$ higher than that of the control device without $\mathrm{Ti}_{3} \mathrm{C}_{2} \mathrm{~T}_{x}$ addition. Moreover, it was found that the $\mathrm{Ti}_{3} \mathrm{C}_{2} \mathrm{~T}_{x}$ addition reduces hysteresis in the current density-voltage $(J-V)$ curves and meanwhile enhances long-time exposure stability of the PSCs. Very (a)

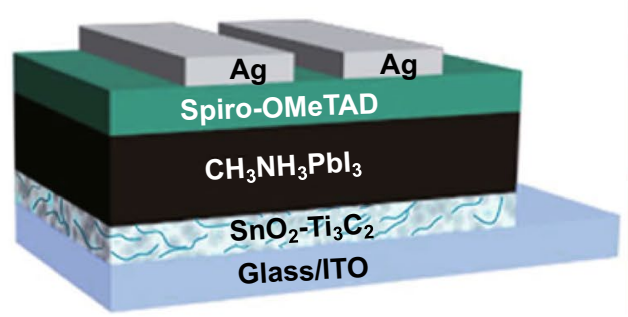

(d)

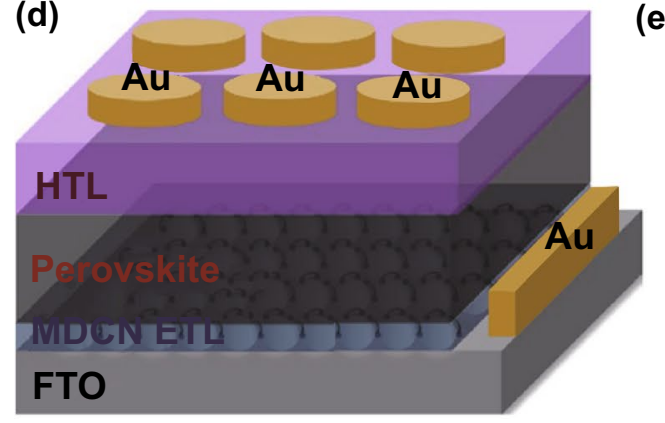

(b)

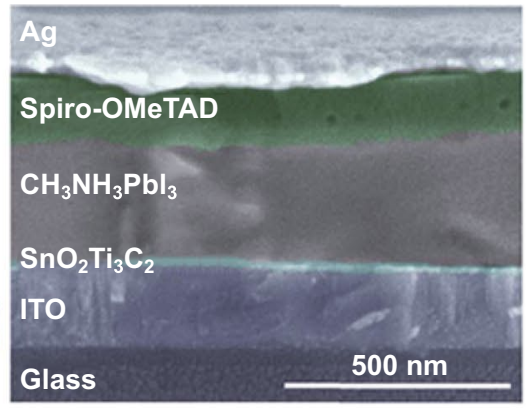

(e)

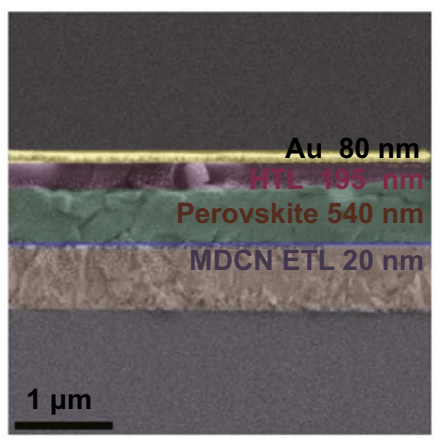

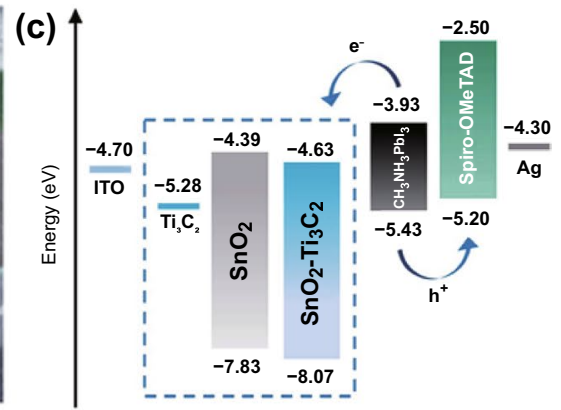

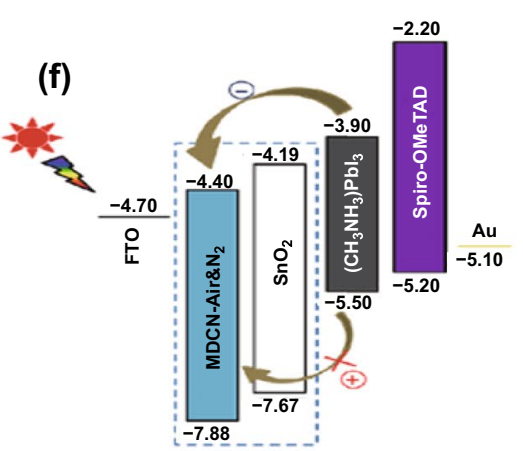

Fig. 3 a Device architecture, b cross-sectional SEM image and $\mathbf{c}$ schematic energy-level diagram of each component for the PV device of ITO/ $\mathrm{Ti}_{3} \mathrm{C}_{2} \mathrm{~T}_{x}$ MXene-added $\mathrm{SnO}_{2}$ ETL/MAPbI ${ }_{3} /$ Spiro-OMeTAD/Ag. Copyright $\odot 2019$ The Royal Society of Chemistry. d Device architecture, e cross-sectional SEM image and $\mathbf{f}$ schematic energy-level diagram of each component for the PSCs using MDCN as the ETL 
recently, this group further investigated the $\mathrm{MAPbI}_{3}$ perovskite/ $\mathrm{Ti}_{3} \mathrm{C}_{2} \mathrm{~T}_{x}$-based MXene interface using density functional theory calculations, and the results show that the interface WF exhibits a strong nonlinear behavior when the relative concentrations of $\mathrm{OH}-$, O- and F-terminating groups are varied, providing a deep insight regarding the energy-level alignment for high-performance device fabrication [63].

Similarly, adding the $\mathrm{Ti}_{3} \mathrm{C}_{2} \mathrm{~T}_{x}$ MXene into HTLs also can improve device performance. Recently, Hou et al. reported modification of the conductive polymer, PEDOT:PSS (poly(3,4-ethylenedioxythiophene):poly(styrenesulfonate)), normally as the HTL in OSCs using the $\mathrm{Ti}_{3} \mathrm{C}_{2} \mathrm{~T}_{x}$ MXene nanosheets [64]. As demonstrated in Fig. 4a, after adding the MXene nanosheets, more charge transfer channels between
PEDOT nanocrystals can be formed. In the meantime, the conformational transformation of PEDOT from a coil structure to a linear/expansion coil structure can be induced, hence leading to the improved electrical conductivity for the modified PEDOT:PSS, as verified by the conductivity measurement shown in Fig. 4b. Using the modified PEDOT:PSS as the HTL, the OSCs based on the non-fullerene PBDBT:ITIC system were constructed, as schematized in Fig. 4c. Thanks to the improved electrical conductivity and matched energy-level alignment with the neighboring components (Fig. 4d) for the $\mathrm{Ti}_{3} \mathrm{C}_{2} \mathrm{~T}_{x}$-modified PEDOT:PSS, a PCE of $11.02 \%$ is achieved as compared to $9.72 \%$ for the control device using pure PEDOT:PSS as the HTL. When using the PM6:Y6 system as the active layer, a PCE of $14.55 \%$ can be (a)
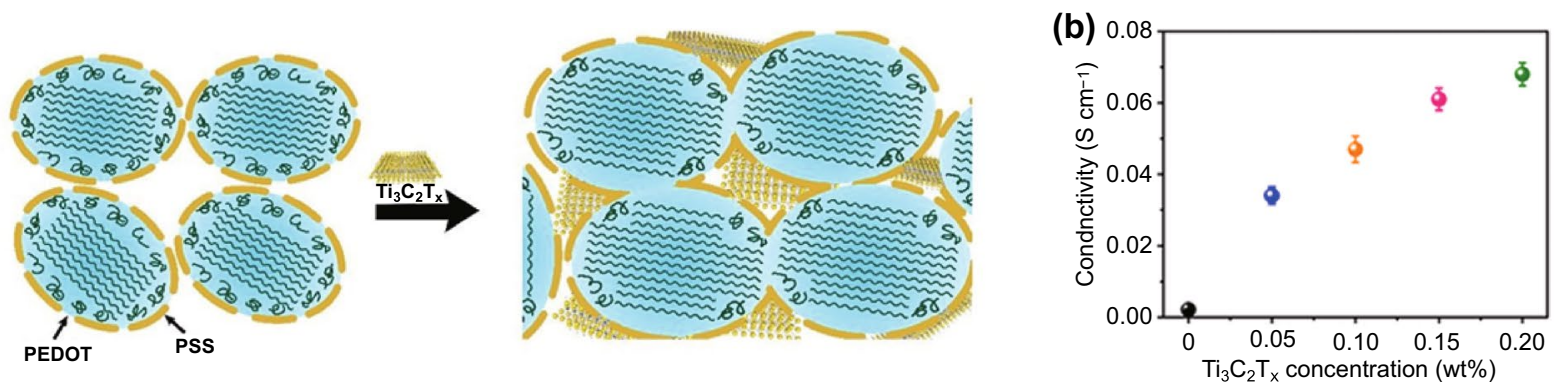

(c)

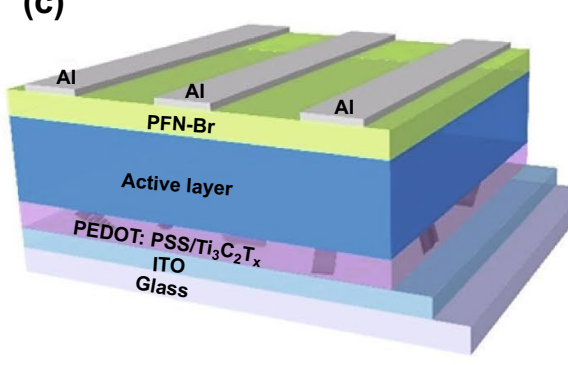

(d)

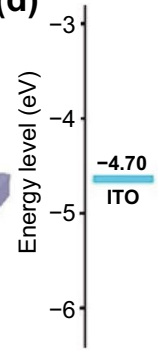

(g)

(f)

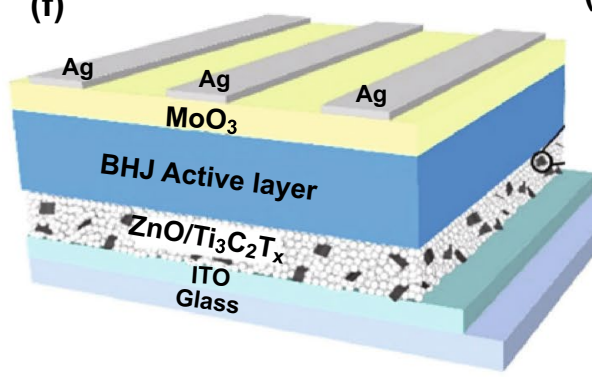

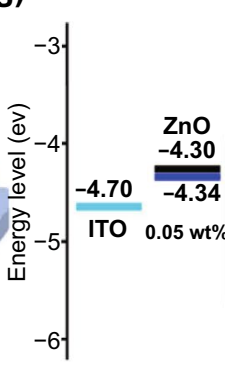
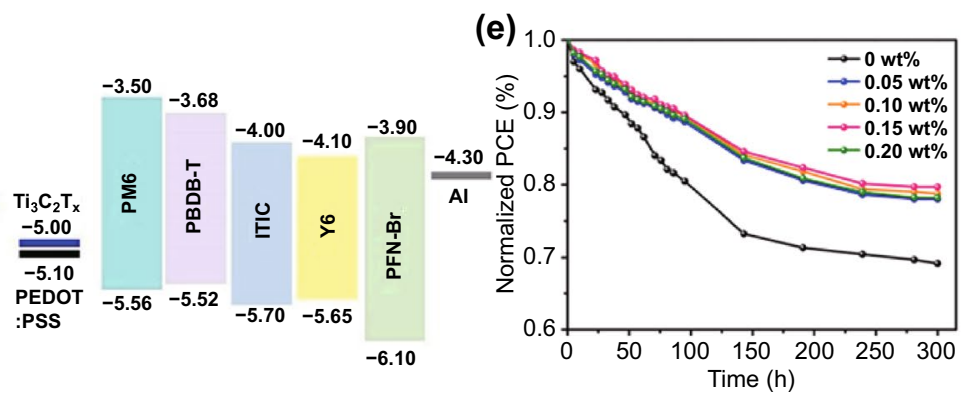

\footnotetext{
(h)
}

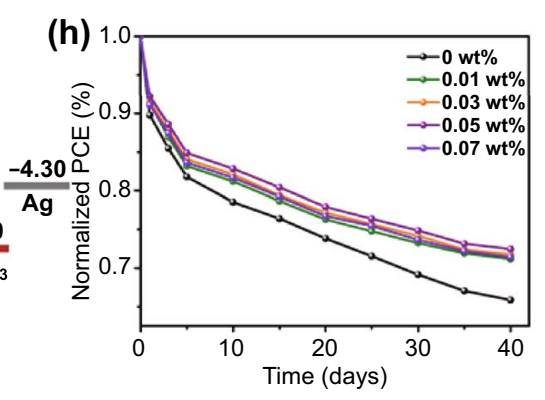

Fig. 4 a Schematic illustration of morphological and structural modification in PEDOT:PSS with incorporation of the Ti ${ }_{3} \mathrm{C}_{2} \mathrm{~T}_{x} \mathrm{MXene}$ nanosheets. b Electrical conductivity of PEDOT:PSS with varying $\mathrm{Ti}_{3} \mathrm{C}_{2} \mathrm{~T}_{x}$ additions on bare glass. $\mathbf{c}$ Device configuration and $\mathbf{d}$ energy-level diagram of each component for the OSC using $\mathrm{Ti}_{3} \mathrm{C}_{2} \mathrm{~T}_{x}$-modified PEDOT:PSS as the HTL. e Stability test for the devices with varying $\mathrm{Ti}_{3} \mathrm{C}_{2} \mathrm{~T}_{x}$ additions based on the PBDB-T:ITIC photoactive layer measured in a $\mathrm{N}_{2}$ glove box. Copyright $\odot$ The Royal Society of Chemistry. $\mathbf{f}$ Device configuration and $\mathbf{g}$ energy-level diagram of each component for the OSC using $\mathrm{ZnO} / \mathrm{Ti}_{3} \mathrm{C}_{2} \mathrm{~T}_{x}$ as the ETL. $\mathbf{h}$ Stability test of the devices based on the PBDB-T:ITIC photoactive with varying $\mathrm{Ti}_{3} \mathrm{C}_{2} \mathrm{~T}_{x}$ additions without encapsulation in air. Copyright $\odot 2020$ Elsevier B.V 
delivered for the case of employing the $\mathrm{Ti}_{3} \mathrm{C}_{2} \mathrm{~T}_{x}$-modified PEDOT:PSS HTL as compared to $13.10 \%$ for the control device using pure PEDOT:PSS. Moreover, appropriate addition of the $\mathrm{Ti}_{3} \mathrm{C}_{2} \mathrm{~T}_{x}$ MXene nanosheets can improve the performance stability, as indicated in Fig. $4 \mathrm{e}$.

Moreover, they also tried to add the $\mathrm{Ti}_{3} \mathrm{C}_{2} \mathrm{~T}_{x}$ MXene nanosheets in zinc oxide $(\mathrm{ZnO})$ to fabricate a novel $\mathrm{ZnO} /$ $\mathrm{Ti}_{3} \mathrm{C}_{2} \mathrm{~T}_{x}$ hybrid ETL by precisely controlling the amount of $\mathrm{Ti}_{3} \mathrm{C}_{2} \mathrm{~T}_{x}$ in the sol-gel $\mathrm{ZnO}$ precursor solution [65]. The nanosheets act as the "electron bridges," as aforementioned [54, 55], between the $\mathrm{ZnO}$ nanocrystals, thus providing additional charge transport pathways. Meanwhile, the $\mathrm{Ti}_{3} \mathrm{C}_{2} \mathrm{~T}_{x}$ MXene passivates the surface of the $\mathrm{ZnO}$ nanocrystals by forming the $\mathrm{Zn}-\mathrm{O}-\mathrm{Ti}$ bonding, through which electrons can transfer. This $\mathrm{ZnO} / \mathrm{Ti}_{3} \mathrm{C}_{2} \mathrm{~T}_{x}$ hybrid ETL with excellent optical and electrical properties was applied in fullerene (PBDBT:ITIC and PM6:Y6) and non-fullerene (PTB7:PC $\left.{ }_{71} \mathrm{BM}\right)$ OSCs (Fig. 4f, $g$ for the architecture and energy-level alignment of the device), and the improved PCEs of $12.20 \%$, $16.51 \%$ and $9.36 \%$ from $10.56 \%, 14.99 \%$ and $8.18 \%$ for the control devices using the pristine ZnO ETLs were achieved by the solar cells based on the PBDB-T:ITIC, PM6:Y6 and
PTB7: $\mathrm{PC}_{71} \mathrm{BM}$ photoactive layers, respectively. Moreover, the improved stability for the devices using the $\mathrm{ZnO} / \mathrm{Ti}_{3} \mathrm{C}_{2} \mathrm{~T}_{x}$ hybrid ETLs was observed, as shown in Fig. 4h.

\subsection{Electrode}

The newly reported electrical conductivity of the $\mathrm{Ti}_{3} \mathrm{C}_{2} \mathrm{~T}_{x}$ MXene has reached as high as $15,100 \mathrm{~S} \mathrm{~cm}^{-1}$ [66], and moreover, high transparency, outstanding flexibility and adjustable WF are associated with it [67-69]. All these properties make $\mathrm{Ti}_{3} \mathrm{C}_{2} \mathrm{~T}_{x}$ suitable as electrodes in optoelectronic devices including solar cells. In the following, the review will be expanded in the sequence of the perovskite-based, organic, Si wafer-based and dyesensitized solar cells.

In 2019, Gao et al. reported use of $\mathrm{Ti}_{3} \mathrm{C}_{2} \mathrm{~T}_{x}$ MXene materials as the back electrode in noble-metal-free $\mathrm{MAPbI}_{3}$-based PSCs through a simple hot-pressing method, and Fig. 5a-c shows the preparation procedure, cross-sectional SEM image and energy-level alignment of each component for the devices [52]. One notes that as the back electrode, the $\mathrm{Ti}_{3} \mathrm{C}_{2} \mathrm{~T}_{x}$ MXene can facilitate

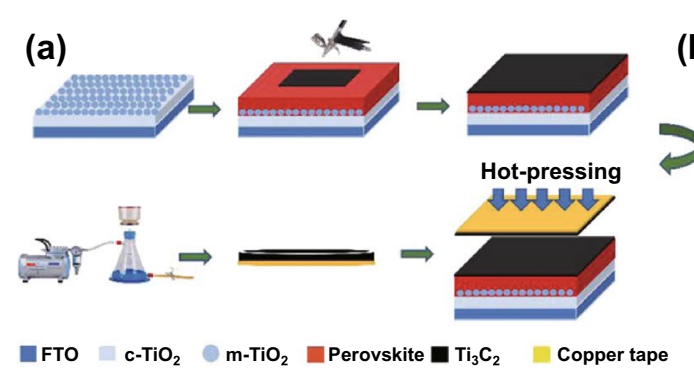

(d)

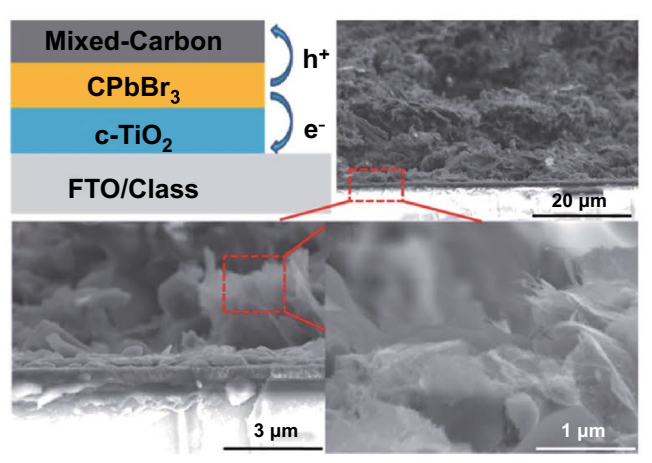

(b)

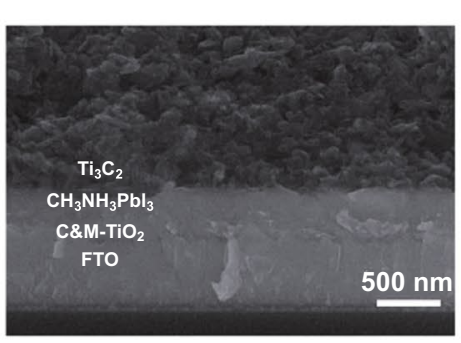

(c)

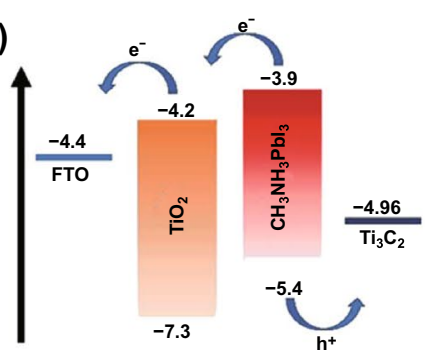

(e)

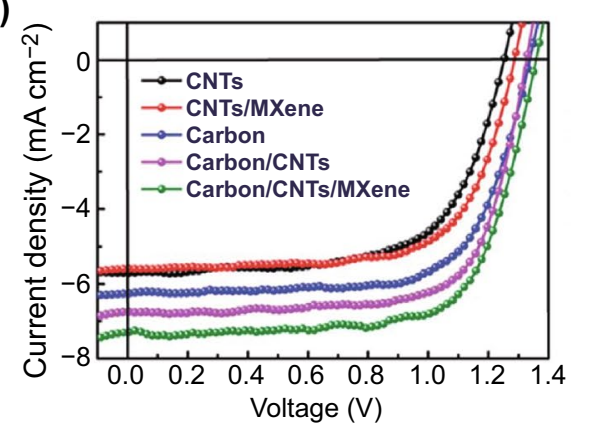

Fig. 5 a Fabrication process of the $\mathrm{MAPbI}_{3}$-based PSCs with a $\mathrm{Ti}_{3} \mathrm{C}_{2} \mathrm{~T}_{x}$ back electrode prepared using a hot-pressing method. b Cross-sectional SEM image and $\mathbf{c}$ energy-level alignment of each component for the MAPbI ${ }_{3}$-based PSCs. Copyright ( $\odot 2019$ The Royal Society of Chemistry. d Device configuration of the $\mathrm{CsPbr}_{3}$-based solar cells using the mixed carbon electrode and cross-sectional SEM images of the mixed carbon electrode. e Illuminated $J-V$ curves of the solar cells with different types of electrodes. Copyright $\odot 2020$ The Royal Society of Chemistry 
hole injection from the $\mathrm{MAPbI}_{3}$ photoactive layer, and the device delivers a PCE of up to $13.83 \%, \sim 27.2 \%$ higher than that of the control device using the carbon electrode. Moreover, thanks to the seamless interfacial contact, the device exhibits improved stability compared with the control one. Recently, Mi et al. employed a mixed electrode consisting of carbon, carbon nanotube $(\mathrm{CNT})$ and $\mathrm{Ti}_{3} \mathrm{C}_{2} \mathrm{~T}_{x}$ in $\mathrm{CsPBr}_{3}$-based PSCs, and Fig. 5d shows the device architecture and the cross-sectional SEM images of the mixed electrode. As indicated in Fig. 5e, the devices using the $\mathrm{Ti}_{3} \mathrm{C}_{2} \mathrm{~T}_{x}$-incorporated electrodes exhibit improved performance compared with the devices employing the electrodes without $\mathrm{Ti}_{3} \mathrm{C}_{2} \mathrm{~T}_{x}$ [70].

In 2019, Tang et al. combined $\mathrm{Ti}_{3} \mathrm{C}_{2} \mathrm{~T}_{x}$ nanosheets with Ag nanowire networks to fabricate the transparent, highly conductive and flexible hybrid electrodes for flexible OSCs that are based on different combinations of organic active materials including PTB7-Th:PC ${ }_{71} \mathrm{BM}$, PBDB-T:ITIC and PBDB-T:ITIC:PC ${ }_{71} \mathrm{BM}$ [71]. This MXene/Ag nanowire hybrid electrode, prepared via a simple and scalable solution-processed method as shown in Fig. 6a, exhibits excellent performance. The flexible ternary (PBDB-T:ITIC:PC ${ }_{71} \mathrm{BM}$ ) OSCs using this hybrid transparent electrode deliver a champion PCE of $8.30 \%$ and meanwhile exhibit robust mechanical performance, i.e., $84.6 \%$ retention of the initial PCE after 1000 bending and unbending cycles to a 5-mm bending radius.

Recently, Qin et al. reported utilization of the $\mathrm{Ti}_{3} \mathrm{C}_{2} \mathrm{~T}_{x}$ MXene thin film as a common electrode to fabricate the MXene-based all-solution-processed semitransparent flexible photovoltaic (PV) supercapacitor by integrating a flexible OSC and a transparent MXene supercapacitor in the vertical direction [72]. Figure $6 \mathrm{~b}$ shows the schematic of the preparation (left), optical photograph (upper right) and cross-sectional demonstration (lower right) of the transparent flexible electrode, and the device configuration and working principle are shown in Fig. 6c. The flexible OSCs with $\mathrm{Ti}_{3} \mathrm{C}_{2} \mathrm{~T}_{x}$ as the transparent electrode can deliver a high PCE of $13.6 \%$, comparable with that of the control device using an ITO electrode. The PV supercapacitor exhibits an average visible transmission of $33.5 \%$ and the maximum storage efficiency and overall efficiency of up to $88 \%$ and (a)

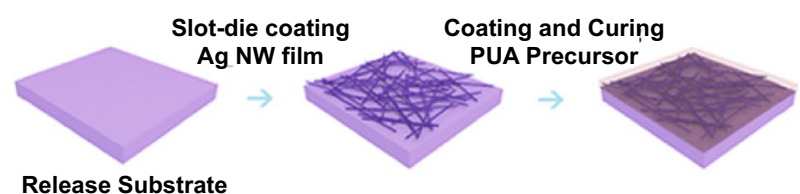

Release Substrate

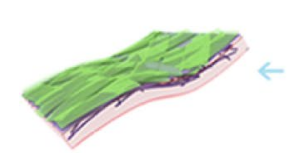

Flexible electrode

(c)

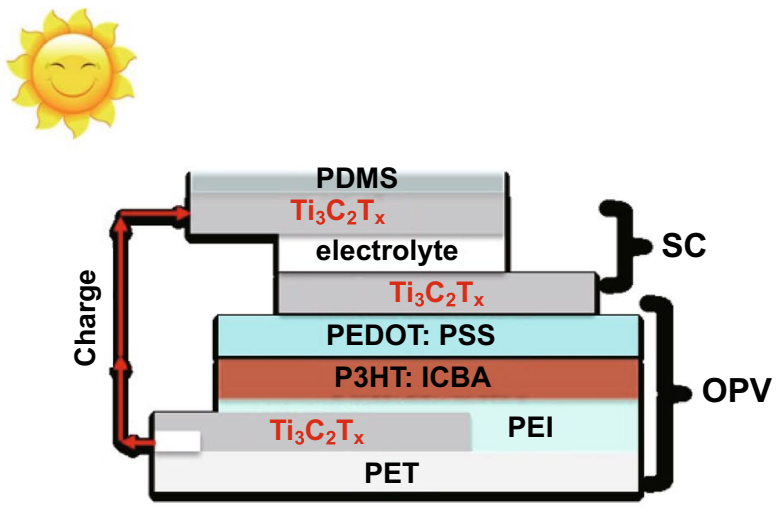

(b)
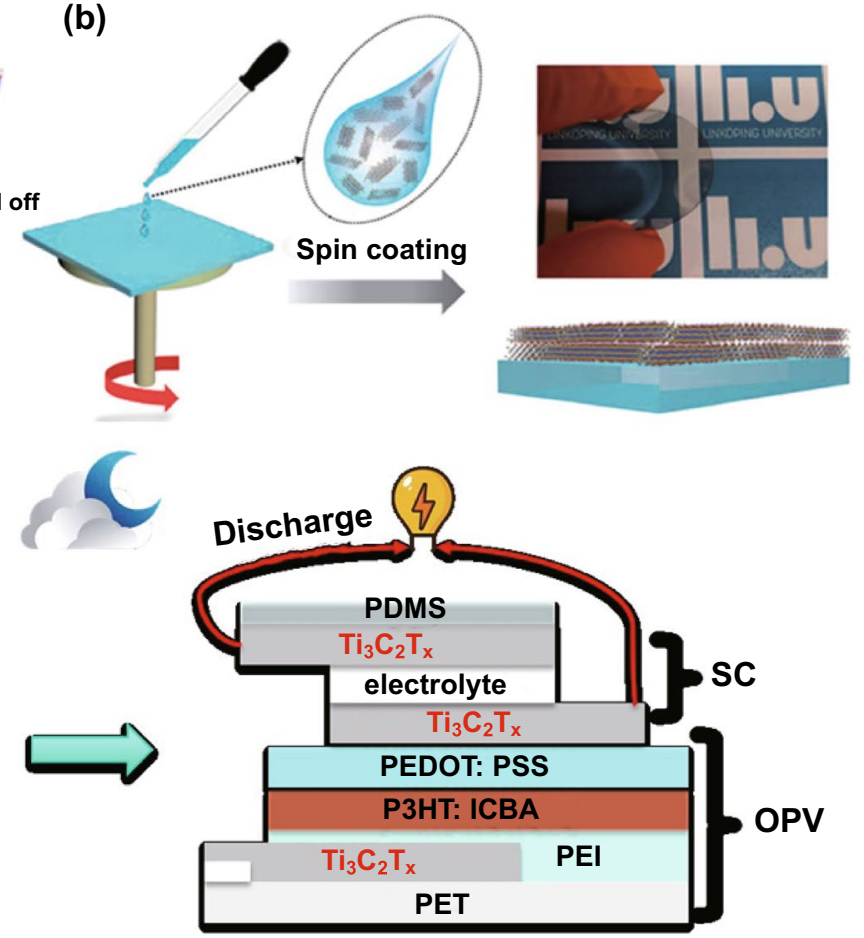

Fig. 6 a Fabrication process of the flexible transparent electrodes based on $\mathrm{Ti}_{3} \mathrm{C}_{2} \mathrm{~T}_{x}$ MXene nanosheets and Ag nanowire networks. Copyright (C) 2019 American Chemical Society. b Schematic of the preparation (left), optical photograph (upper right) and cross-sectional demonstration (lower right) of the $\mathrm{Ti}_{3} \mathrm{C}_{2} \mathrm{~T}_{x}$ transparent flexible electrode for the PV supercapacitors. c Working principle of the semitransparent, flexible PV supercapacitor in the charge (left) and discharge states. Copyright @ 2020 The Royal Society of Chemistry 
$2.2 \%$, respectively. In addition, this strategy is suitable for blading, printing and roll-to-roll manufacturing, which is promising for the production of cost-efficient flexible PV supercapacitors to satisfy the increasing energy demands for portable, wearable and miniature electronic devices.

In 2019, Fu et al. drop-casted the $\mathrm{Ti}_{3} \mathrm{C}_{2} \mathrm{~T}_{x}$ MXene solution on the groove surface of the $n^{+}-\mathrm{Si}$ emitter as the back electrode in an $n^{+}-n-p^{+}$Si solar cell (see Fig. $7 \mathrm{a}-\mathrm{c}$ for the device architecture, groove surface before and after MXene coating) [73]. The ohmic contact between $\mathrm{Ti}_{3} \mathrm{C}_{2} \mathrm{~T}_{x}$ and $n^{+}$$\mathrm{Si}$ (see Fig. 7d for the energy-level alignment) facilitates electron transfer from the $n^{+}$-Si emitter and thus suppresses charge carrier recombination, resulting in good output of the short-circuit current density $\left(J_{\mathrm{sc}}\right)$ and open-circuit voltage $\left(V_{\mathrm{oc}}\right)$. Moreover, it was found that the rapid thermal annealing (RTA) treatment of $30 \mathrm{~s}$ can further improve the electrical contact and physical adhesion between the MXene coating and the $n^{+}$-Si substrate, leading to the reduced series resistance (it can be concluded from the increased slope for the $J-V$ curves around $V_{\text {oc }}$ in Fig. 7e and also verified by the resistance measurement, as exhibited in Fig. 7f) and thus a remarkable improvement of PCE to $11.5 \%$. In some cases, MXenes serve both the electrode and the component of forming the Schottky junction with Si. For example, Yu et al. reported a Schottky junction solar cell fabricated based on $\mathrm{Ti}_{3} \mathrm{C}_{2} \mathrm{~T}_{x}$ and $n$-Si, where the $\mathrm{Ti}_{3} \mathrm{C}_{2} \mathrm{~T}_{x}$ electrode meanwhile serves as a transparent conducting film for charge collection, as shown in Fig. 10a (later) [74]. For this content, we would like to more detailedly discuss in the following part of MXenes as HTLs/ETLs.

The $\mathrm{Ti}_{3} \mathrm{C}_{2} \mathrm{~T}_{x}$ MXene was also employed to fabricate the counter electrode (CE) in quantum dot-sensitized solar cells (QDSCs). In 2019, Chen et al. reported a composite $\mathrm{CE}$ consisting of hydrothermally grown $\mathrm{CuSe}$ nanoparticles on $\mathrm{Ti}_{3} \mathrm{C}_{2} \mathrm{~T}_{x}$ MXene nanosheets that were screenprinted onto a graphite sheet [75]. This composite CE possesses the better electrical conductivity for electron transfer and a larger specific surface area to provide more active sites for polysulfide electrolyte reduction, as compared to $\mathrm{CuSe}$ - and $\mathrm{Ti}_{3} \mathrm{C}_{2} \mathrm{~T}_{x}$-based CEs, respectively. The PCE of $5.12 \%$ can be achieved by the device using the $\mathrm{CuSe} / \mathrm{Ti}_{3} \mathrm{C}_{2} \mathrm{~T}_{x}$ composite $\mathrm{CE}$ with an optimal mass ratio. As a comparison, the devices using the CuSe- and $\mathrm{Ti}_{3} \mathrm{C}_{2} \mathrm{~T}_{x}$-based CEs deliver the PCE of $3.47 \%$ and $2.04 \%$, (a)

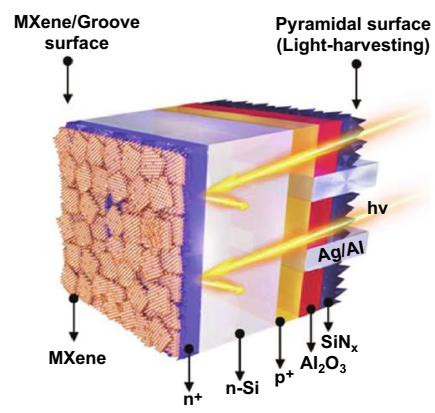

(d)

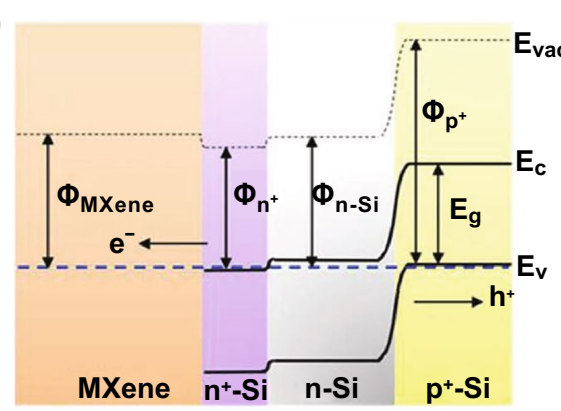

(b)

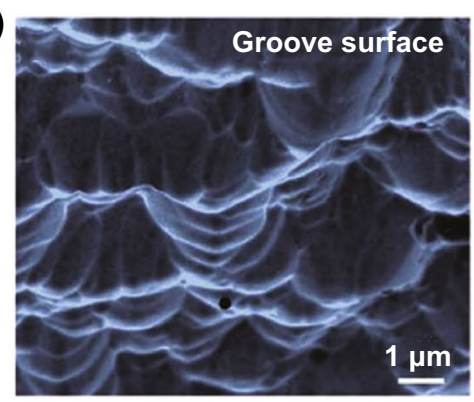

(e)

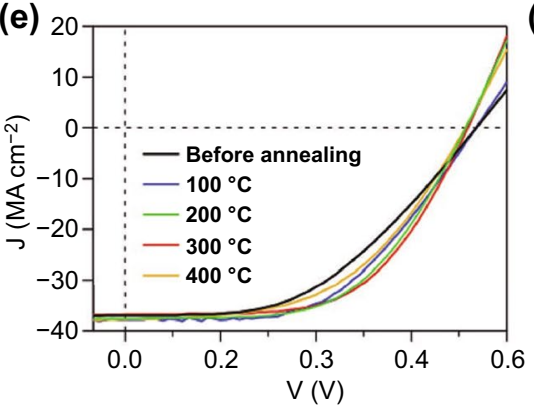

(c)

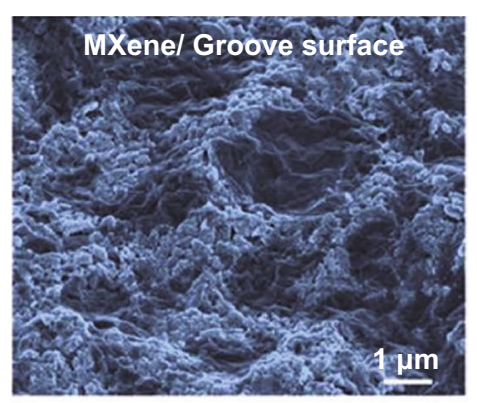

(f)

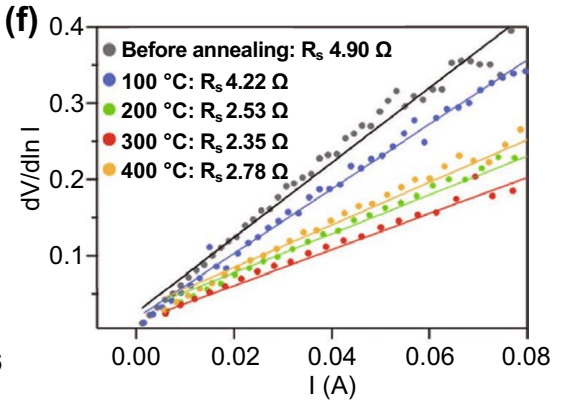

Fig. 7 a Schematic illustration for the $n^{+}-p-p^{+} \mathrm{Si}$ solar cell using the $\mathrm{Ti}_{3} \mathrm{C}_{2} \mathrm{~T}_{x}$ MXene as the electrode contacted with the $n^{+}$emitter. SEM images of grooves on the $n^{+}$side surface $\mathbf{b}$ before and $\mathbf{c}$ after MXene coating. $\mathbf{d}$ Energy-level alignment. $\Phi$ is a work function; $E_{\mathrm{g}}, E_{\mathrm{c}}$ and $E_{\mathrm{v}}$ are the energy bandgap, conduction band and valence band of Si. e Illuminated $J$ - $V$ curves before and after $30 \mathrm{~s}$ RTA treatment at varying temperatures. f Series resistance values deduced from the $J-V$ measurement for the samples before and after the RTA process. Copyright $\odot 2019$ WILEY-VCH Verlag GmbH \& Co. KGaA, Weinheim 
respectively. Similarly, Tian et al. fabricated the $\mathrm{CuS} /$ $\mathrm{Ti}_{3} \mathrm{C}_{2}$ composite CEs via a facile ion-exchange method at room temperature, exhibiting a significantly faster electrocatalytic rate toward the polysulfide reduction than pure $\mathrm{CuS}$ [76]. The QDSC based on this composite CE delivers an overall PCE of $5.11 \%$, which is 1.5 times obtained from the device using the pure $\mathrm{CuSCE}$. The performance enhancement is mainly attributed to the combined advantages of the excellent conductivity of the $\mathrm{Ti}_{3} \mathrm{C}_{2}$ skeleton and the abundant catalytically active sites of the $\mathrm{CuS}$ nanoparticles.

\section{$2.3 \mathrm{HTL} / \mathrm{ETL}$}

Owing to the easily tunable WF, the $\mathrm{Ti}_{3} \mathrm{C}_{2} \mathrm{~T}_{x}$ MXene can also be applied as an HTL or ETL, and the related reports in PSCs, OSCs and crystalline Si solar cells can be found. In 2019, Chen et al. reported insertion of $\mathrm{Ti}_{3} \mathrm{C}_{2} \mathrm{~T}_{x}$ nanosheets between the $\mathrm{CsPbBr}_{3}$ active layer and the carbon electrode as the HTL [77], as indicated in Fig. 8a. The electron potential barrier because of the inserted $\mathrm{Ti}_{3} \mathrm{C}_{2} \mathrm{~T}_{x}$ layer (Fig. $8 \mathrm{~b}, \mathrm{c}$ ) effectively blocks the transfer of electrons from $\mathrm{CsPbBr}_{3}$ to the carbon electrode and thus mitigates the electron-hole (a)

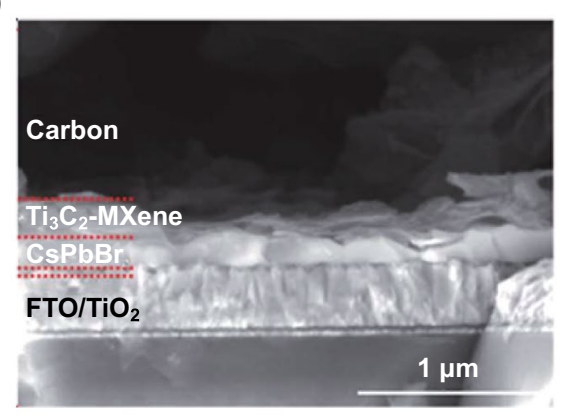

(d)

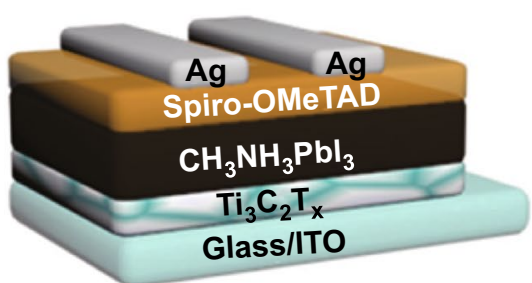

(g)

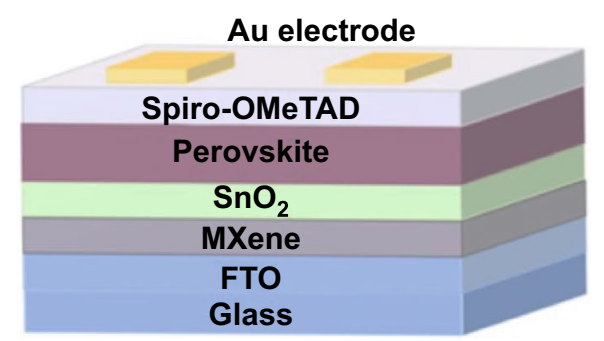

(b)

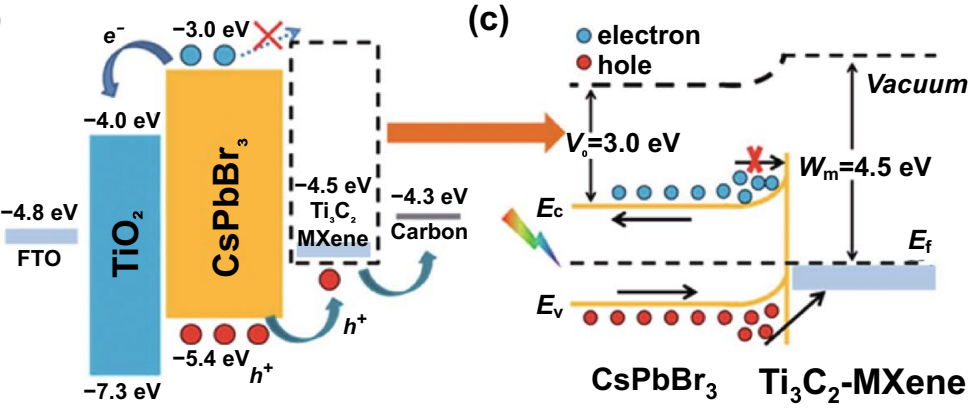

(e)
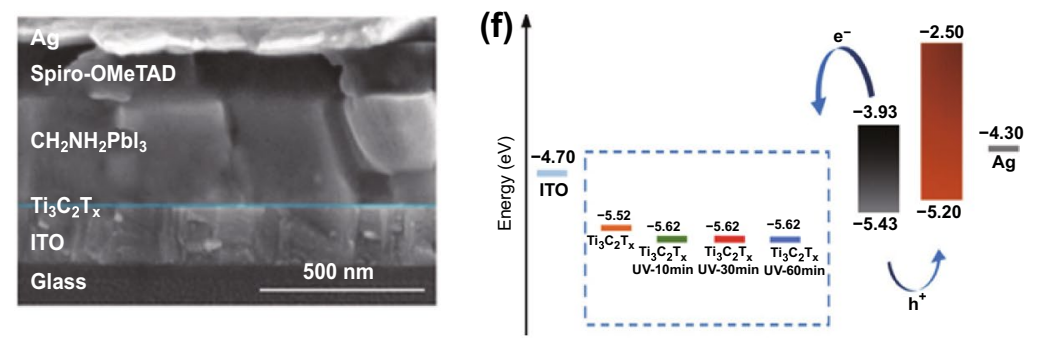

(h)

(i)

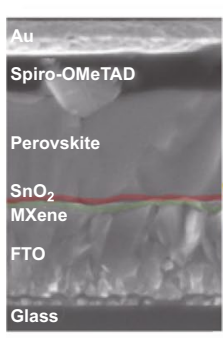

Fig. $8 \mathrm{CsPbBr}_{3}$-based PSCs using the $\mathrm{Ti}_{3} \mathrm{C}_{2} \mathrm{~T}_{x}$ nanosheet layer as the HTL: a Cross-sectional SEM image, $\mathbf{b}$ energy-level alignment and $\mathbf{c}$ carrier transport mechanism at illumination. Copyright (C) 2019 The Royal Society of Chemistry. d Device architecture and e cross-sectional SEM image, f energy-level alignment of each layer. Copyright (c) 2019 WILEY-VCH Verlag GmbH \& Co. KGaA, Weinheim. g Device configuration and $\mathbf{h}$ energy-level alignment of the device. $\mathbf{i}$ Cross-sectional SEM image of the device (left), first-principle optimized structures and electron density differences for $\mathrm{SnO}_{2} / \mathrm{Ti}_{3} \mathrm{C}_{2}(\mathrm{OH})_{2}$ (upper right), and spatially resolved mapping of the current transport efficiency of the MXene-inserted device (lower right). Copyright (C) 2020 American Chemical Society 
recombination. In addition, the $\mathrm{CsPbBr}_{3}$ grains can be well passivated by the functional groups in $\mathrm{Ti}_{3} \mathrm{C}_{2} \mathrm{~T}_{x}$, thus reducing the trap defects in the $\mathrm{CsPbBr}_{3}$ film and improving the perovskite film quality. A high initial PCE of 9.01\% is obtained for the PSCs with long-term stability for more than $1900 \mathrm{~h}$ in a moisture environment and over $600 \mathrm{~h}$ under thermal conditions.

In the same year, employing the $\mathrm{Ti}_{3} \mathrm{C}_{2} \mathrm{~T}_{x}$ layer as a novel ETL for $\mathrm{MAPbI}_{3}$-based PSCs was reported by Yang et al. [78], and Fig. 8d, e shows the device architecture and crosssectional SEM image of the solar cell. Under the assistance of ultraviolet-ozone (UV-O ${ }_{3}$ ) treatment, the Fermi level of $\mathrm{Ti}_{3} \mathrm{C}_{2} \mathrm{~T}_{x}$ could be downshifted from -5.52 to $-5.62 \mathrm{eV}$, as indicated in Fig. 8f, and meanwhile, the interface properties between $\mathrm{Ti}_{3} \mathrm{C}_{2} \mathrm{~T}_{x}$ and $\mathrm{MAPbI}_{3}$ were improved because of the formation of the additional oxide-like Ti-O bonds on the surface of $\mathrm{Ti}_{3} \mathrm{C}_{2} \mathrm{~T}_{x}\left(\mathrm{Ti}_{3} \mathrm{C}_{2} \mathrm{O}_{2}\right)$. Thanks to the enhanced hole blocking because of the downshifted Fermi level of $\mathrm{Ti}_{3} \mathrm{C}_{2} \mathrm{~T}_{x}$ and meanwhile to the improved $\mathrm{MAPbI}_{3} / \mathrm{Ti}_{3} \mathrm{C}_{2} \mathrm{~T}_{x}$ interface, a champion PCE of $17.17 \%$ was thus achieved for the device employing the $\mathrm{Ti}_{3} \mathrm{C}_{2} \mathrm{~T}_{x}$ MXene film with $30 \mathrm{~min}$ $\mathrm{UV}-\mathrm{O}_{3}$ treatment. However, the device using $\mathrm{Ti}_{3} \mathrm{C}_{2} \mathrm{~T}_{x}$ without $\mathrm{UV}-\mathrm{O}_{3}$ treatment only delivers the $5.00 \%$ PCE. Further investigations verified that the charge transfer was truly enhanced for the case with the optimal UV-O ${ }_{3}$ treatment of $30 \mathrm{~min}$, as indicated by the EIS measurement. In addition, $\mathrm{UV}-\mathrm{O}_{3}$ treatment to $\mathrm{Ti}_{3} \mathrm{C}_{2} \mathrm{~T}_{x}$ also contributes to improve the device stability.

Recently, Wang et al. reported a perovskite solar cell with a thin $\mathrm{Ti}_{3} \mathrm{C}_{2} \mathrm{~T}_{x}$ MXene layer inserted between the F-doped $\mathrm{SnO}_{2}$ (FTO) electrode and the $\mathrm{SnO}_{2}$ ETL [79], and Fig. 8g, i shows the architecture and cross-sectional SEM image of the device. As indicated in Fig. 8h, the inserted MXene thin layer is favorable to form matched energy-level alignment between FTO and the $\mathrm{SnO}_{2}$ ETL, thus facilitating electron transport from $\mathrm{SnO}_{2}$ to FTO. Meanwhile, the strong interaction and electron hybridization between $\mathrm{MXene}$ and $\mathrm{SnO}_{2}$ can be introduced (see Fig. 8i for the simulated structure), thus leading to the enhanced electron mobility in $\mathrm{SnO}_{2}$. Moreover, the surface of the $\mathrm{SnO}_{2}$ ETL becomes more hydrophobic and smoother than the case without MXene, which is beneficial for growing high-quality perovskite layers. It was also found that compared with the case without MXene, non-radiative recombinations were significantly suppressed by the MXene-modified $\mathrm{SnO}_{2}$ ETL together with the remarkably improved homogeneity and reduced carrier transport loss (Fig. 8i). Thanks to these synergetic effects introduced by the MXene thin layer, the related device delivers a stabilized PCE of $20.65 \%(<19.00 \%$ for the control device without MXene) with an ultralow saturated current density and negligible hysteresis.

In 2019, Yu et al. reported utilization of the UV-O $\mathrm{O}_{3}$ treatment or $\mathrm{N}_{2} \mathrm{H}_{4}$ treatment to increase or decrease the WF of $\mathrm{Ti}_{3} \mathrm{C}_{2} \mathrm{~T}_{x}$ (in a range between 4.08 and $4.95 \mathrm{eV}$ ) because of the oxidation or reduction of the $\mathrm{C}$ element, respectively [53]. As shown in Fig. 9a, the $\mathrm{Ti}_{3} \mathrm{C}_{2} \mathrm{~T}_{x}$ MXenes with different WFs can be used as either the HTLs or ETLs for the OSCs employing PBDB-T:ITIC as the photoactive layer. The PCEs of $9.06 \%$ and $9.02 \%$ were obtained for the cases using $\mathrm{Ti}_{3} \mathrm{C}_{2} \mathrm{~T}_{x}$ as electron and hole-collection buffer layers, respectively (Fig. 9b). Moreover, it was found that $V_{\mathrm{oc}}$ increases with the treatment duration, as exhibited in Fig. 9c. In the same year, Hou et al. also reported employment of $\mathrm{Ti}_{3} \mathrm{C}_{2} \mathrm{~T}_{x}$ as the HTLs in PBDB-T:ITIC-based OSCs to facilitate hole transport and collection, benefiting from the outstanding metallic conductivity of $\mathrm{Ti}_{3} \mathrm{C}_{2} \mathrm{~T}_{x}$, improved interface contact and matched energy-level alignment as exhibited in Fig. 9d [80]. It is notable that evident enhancement of PCE can be achieved for the devices using $\mathrm{Ti}_{3} \mathrm{C}_{2} \mathrm{~T}_{x}$ as the HTLs compared with the control one only using ITO (PCE: $4.21 \%$ ). Moreover, the optimal $\mathrm{Ti}_{3} \mathrm{C}_{2} \mathrm{~T}_{x}$-based device also outperforms the state-of-the-art PEDOT:PSS-based device, i.e., $10.53 \%$ vs. $10.11 \%$ (see Fig. 9e for the device performance comparison). Meanwhile, the $\mathrm{Ti}_{3} \mathrm{C}_{2} \mathrm{~T}_{x}$-based devices also exhibit the improved long-term stability under the atmosphere condition without any encapsulations, as indicated in Fig. 9f.

As briefly aforementioned, in 2019, Yu et al. reported a novel solar cell formed by depositing the $\mathrm{Ti}_{3} \mathrm{C}_{2} \mathrm{~T}_{x}$ MXene on $n$-Si, where $\mathrm{Ti}_{3} \mathrm{C}_{2} \mathrm{~T}_{x}$ serves as both the electrode for hole collection and the component to form the Schottky junction with $n$-Si [74], as demonstrated in Fig. 10a. Figure $10 \mathrm{~b}$ shows the illuminated $J-V$ curves for the devices prepared by depositing MXene using floating and oven transfer methods, respectively, with the initial efficiencies of $0.58 \%$ and $4.20 \%$. Moreover, as exhibited in Fig. 10c, the PCE of the as-prepared device by oven transfer can be further improved, i.e., $>9 \%$ by a two-step chemical treatment using $\mathrm{HCl}$ and $\mathrm{AuCl}_{3}$ in sequence and $>10 \%$ by further introducing a PDMS antireflection layer. More investigations indicate that the $\mathrm{SiO}_{2}$ thin layer formed between $\mathrm{Ti}_{3} \mathrm{C}_{2} \mathrm{~T}_{x}$ and $n$-Si during oven transfer plays the key role to suppress 
(a)

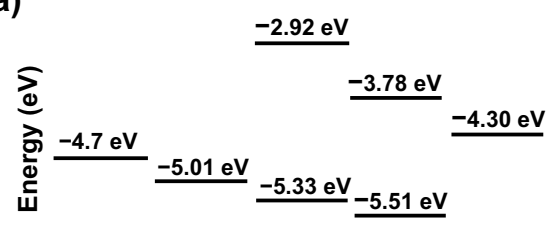

ITO U-MXene PBDB-T ITIC UH-MXene

(d)

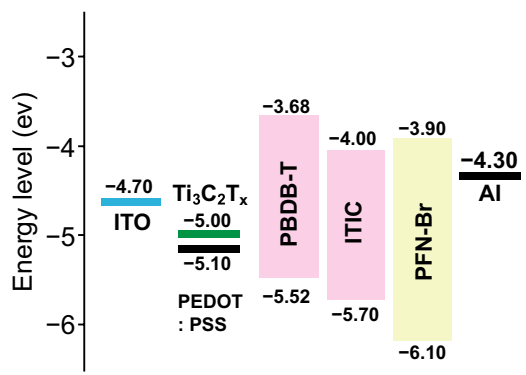

(b)

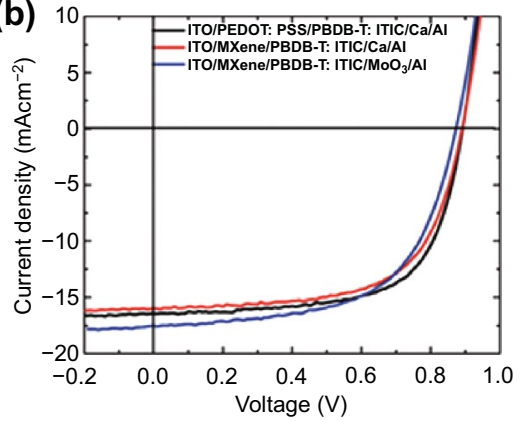

(e)

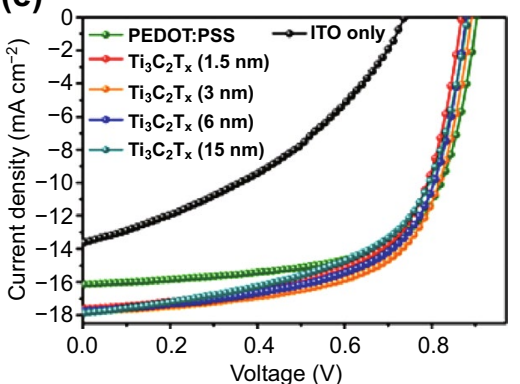

(c)

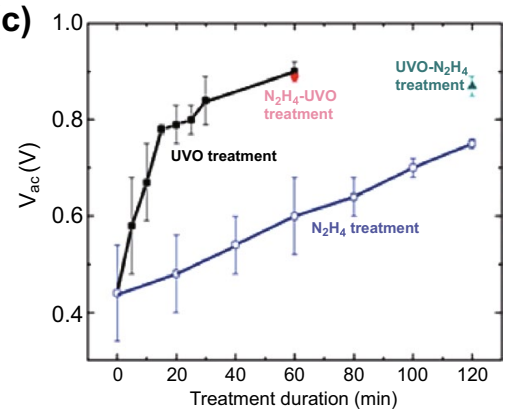

(f)

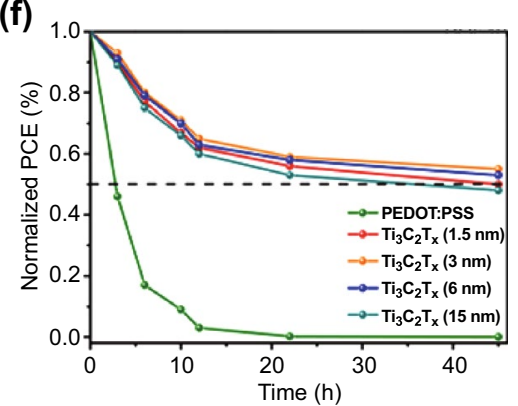

Fig. 9 PBDB-T:ITIC-based OSCs using the UV-O $\mathrm{O}_{3}$ and/or $\mathrm{N}_{2} \mathrm{H}_{4}$-treated $\mathrm{Ti}_{3} \mathrm{C}_{2} \mathrm{~T}_{x}$ MXene as the ETL/HTL: a Energy levels of the main components and $\mathbf{b}$ illuminated $J-V$ curves of the PBDB-T:ITIC-based OSCs. Here, U-MXene and UH-MXene denote the MXene treated only by $\mathrm{UV}-\mathrm{O}_{3}$, and first by $\mathrm{UV}-\mathrm{O}_{3}$ and then by $\mathrm{N}_{2} \mathrm{H}_{4}$, respectively. Moreover, U-MXene is used for the hole collection in the normal OSCs, and the UH-MXene is for the electron collection in the inverted OSCs; and $\mathbf{c} V_{\text {oc }}$ versus the treatment duration. Copyright (C) 2019 The Royal Society of Chemistry. PBDB-T:ITIC-based OSCs using $\mathrm{Ti}_{3} \mathrm{C}_{2} \mathrm{~T}_{x}$ nanosheets as the HTL: d Energy-level alignment of each component, e illuminated $J-V$ curves, and $\mathbf{f}$ stability test under the atmosphere condition without any encapsulations. Copyright $\odot 2019$ The Royal Society of Chemistry

carrier recombinations and thus to achieve the higher device performance as compared to the floating method. For the improved device performance by the two-step chemical treatment, it can be attributed to the increased conductivity for the MXene layer due to the doping effect introduced by
$\mathrm{HCl}$, the increased Schottky barrier height (note: The WF of the MXene layer increases from 4.80 to 4.84 and further to $4.93 \mathrm{eV}$ for the pristine, $\mathrm{HCl}$ - and $\mathrm{AuCl}_{3}$-treated samples) and enhanced charge transfer because of the formed Au nanoparticles from $\mathrm{AuCl}_{3}$. (a)

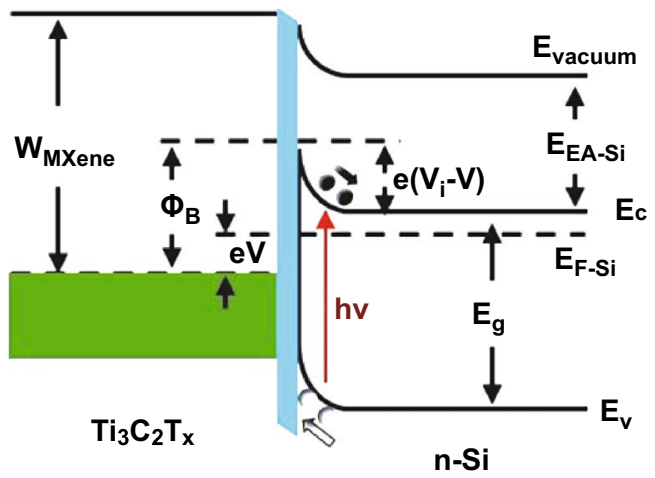

(b)

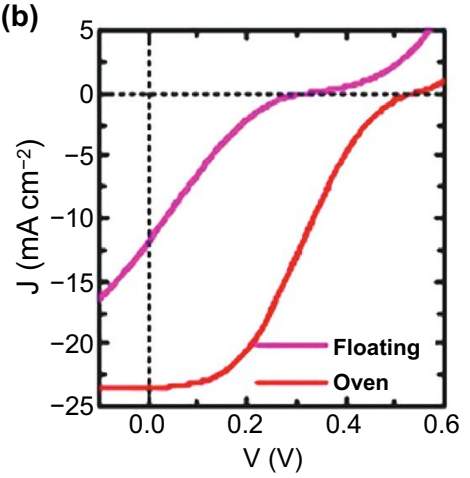

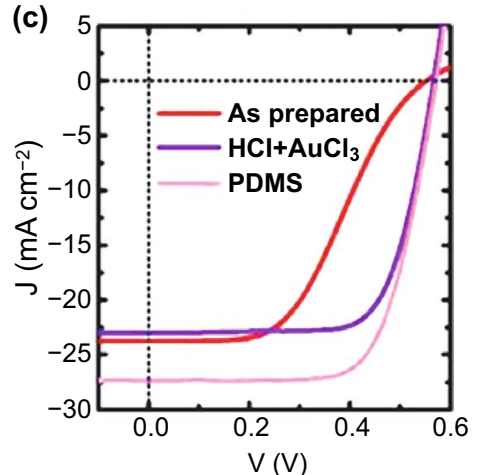

Fig. $10 \mathrm{Ti}_{3} \mathrm{C}_{2} \mathrm{~T}_{x}$ MXene/ $n$-Si solar cells: a Energy-level alignment of the main components (the blue strip indicates the $\mathrm{SiO}_{2}$ thin layer), $\mathbf{b}$ illuminated $J-V$ curves for the devices fabricated via floating and oven transfer methods and $\mathbf{c}$ illuminated $J-V$ curves for the devices fabricated by the oven transfer method and after the two-step $\left(\mathrm{HCl}+\mathrm{AuCl}_{3}\right)$ chemical treatment and further coating the PDMS antireflection film. Copyright (C) 2019 WILEY-VCH Verlag GmbH \& Co. KGaA, Weinheim 
Table 1 Summary of the functions/properties of MXenes in different roles played in solar cells

\begin{tabular}{cc}
\hline Additive & $\begin{array}{c}\text { Accelerating the electron transfer, like an "electron" } \\
\text { bridge } \\
\text { Improving crystallinity of the perovskite materials } \\
\text { Tuning the work function of the carrier transport materi- } \\
\text { als and other properties such as conductivity } \\
\text { Passivating the surface and engineering interface } \\
\text { Electrode } \\
\text { Metallic conductivity, high transparency, outstanding } \\
\text { flexibility and adjustable work functions } \\
\text { To form hybrid electrodes with other conducting } \\
\text { nanomaterials, such as carbon nanotubes or metallic } \\
\text { nanowires } \\
\text { Easily tunable work functions and carrier conducting } \\
\text { properties }\end{array}$ \\
\hline
\end{tabular}

\section{Conclusion and Prospect}

In this review, all applications and developments of the $\mathrm{Ti}_{3} \mathrm{C}_{2} \mathrm{~T}_{x}$ MXene in solar cells since the first report in 2018 are detailedly summarized. As can be seen, the $\mathrm{Ti}_{3} \mathrm{C}_{2} \mathrm{~T}_{x}$
MXene mainly plays three roles, i.e., additive, electrode and charge (electron or hole) transport layer, and the type of the applied solar cells includes perovskite (mainly), organic (mainly), silicon wafer-based and quantum dotsensitized solar cells. (Note: The functions in different roles for MXenes applied in solar cells are briefly summarized in Table 1, and meanwhile, the key device parameters are compiled in Tables 2, 3 and 4, according to the roles played by the $\mathrm{Ti}_{3} \mathrm{C}_{2} \mathrm{~T}_{x}$ MXene.) Moreover, there is one report regarding a hybrid device combining electricity generation and storage, i.e., the so-called PV supercapacitor in which all electrodes are $\mathrm{Ti}_{3} \mathrm{C}_{2} \mathrm{~T}_{x}$, and the organic PV device and supercapacitor share one common electrode [72].

Generally speaking, report of MXenes in application of solar cells just began since the last quarter of 2018, and the related study is still in its infant stage mainly focusing on exploration of the feasibility in varying solar cells. Device performance including PCE and stability still has plenty of room for improvement [81]. Moreover, the influence of

Table 2 Summary of the key parameters for the solar cells employing MXenes as an additive

\begin{tabular}{|c|c|c|c|c|c|c|}
\hline Device structure & $J_{\mathrm{sc}}\left(\mathrm{mA} \mathrm{cm}^{-2}\right)$ & $V_{\mathrm{oc}}(\mathrm{V})$ & $\mathrm{FF}(\%)$ & PCE $(\%)$ & Year & References \\
\hline $\mathrm{ITO} / \mathrm{SnO}_{2} / \mathrm{MAPbI}_{3}: \mathrm{Ti}_{3} \mathrm{C}_{2} \mathrm{~T}_{x} /$ Spiro-OMeTAD/Au & 22.26 & 1.03 & 76.00 & 17.41 & 2018 & {$[51]$} \\
\hline $\mathrm{FTO} / \mathrm{c}-\mathrm{TiO}_{2} / \mathrm{m}-\mathrm{TiO}_{2} / \mathrm{CsFAMA-TQD} /$ Spiro-OMeTAD $: \mathrm{Cu}_{1.8} \mathrm{~S} / \mathrm{Au}$ & 24.12 & 1.14 & 78.70 & 21.64 & 2020 & {$[60]$} \\
\hline $\mathrm{ITO} / \mathrm{SnO}_{2}-\mathrm{Ti}_{3} \mathrm{C}_{2} / \mathrm{MAPbI}_{3} /$ Spiro-OMeTAD$/ \mathrm{Ag}$ & 23.14 & 1.06 & 75.00 & 18.34 & 2019 & {$[61]$} \\
\hline $\mathrm{FTO} / \mathrm{TiO}_{2}: \mathrm{SnO}_{2}: \mathrm{Ti}_{3} \mathrm{C}_{2} \mathrm{~T}_{x} /\left(\mathrm{FAPbI}_{3}\right)_{0.97}\left(\mathrm{MAPbBr}_{3}\right)_{0.03} /$ Spiro-OMeTAD/Au & 22.03 & 1.10 & 77.78 & 18.90 & 2020 & {$[62]$} \\
\hline $\begin{array}{l}\mathrm{FTO} / \mathrm{c}-\mathrm{TiO}_{2}: \mathrm{Ti}_{3} \mathrm{C}_{2} \mathrm{~T}_{x} / \mathrm{m}-\mathrm{TiO}_{2}: \mathrm{Ti}_{3} \mathrm{C}_{2} \mathrm{~T}_{x} / \mathrm{Ti}_{3} \mathrm{C}_{2} \mathrm{~T}_{x} / \mathrm{MAPbI}_{3}: \mathrm{Ti}_{3} \mathrm{C}_{2} \mathrm{~T}_{x} / \text { Spiro- } \\
\text { OMeTAD/Au }\end{array}$ & 23.82 & 1.09 & 77.60 & 20.14 & 2019 & {$[58]$} \\
\hline ITO/PEDOT:PSS: $\mathrm{Ti}_{3} \mathrm{C}_{2} \mathrm{~T}_{x} / \mathrm{PBDB}-\mathrm{T}: I T I C / P F N-B r / A l$ & 17.08 & 0.91 & 70.93 & 11.02 & 2020 & {$[64]$} \\
\hline ITO/PEDOT:PSS: $\mathrm{Ti}_{3} \mathrm{C}_{2} \mathrm{~T}_{x} / \mathrm{PM} 6: \mathrm{Y} 6 / \mathrm{PFN}-\mathrm{Br} / \mathrm{Al}$ & 25.63 & 0.83 & 68.40 & 14.55 & 2020 & {$[64]$} \\
\hline ITO/ZnO: $\mathrm{Ti}_{3} \mathrm{C}_{2} \mathrm{~T}_{x} / \mathrm{PBDB}-\mathrm{T}: \mathrm{ITIC} / \mathrm{MoO}_{3} / \mathrm{Ag}$ & 18.63 & 0.93 & 70.39 & 12.20 & 2020 & {$[65]$} \\
\hline ITO/ZnO: $\mathrm{Ti}_{3} \mathrm{C}_{2} \mathrm{~T}_{x} / \mathrm{PM} 6: \mathrm{Y} 6 / \mathrm{MoO}_{3} / \mathrm{Ag}$ & 26.38 & 0.83 & 75.40 & 16.51 & 2020 & {$[65]$} \\
\hline ITO/ZnO: $\mathrm{Ti}_{3} \mathrm{C}_{2} \mathrm{~T}_{x} / \mathrm{PTB} 7: \mathrm{PC}_{71} \mathrm{BM} / \mathrm{MoO}_{3} / \mathrm{Ag}$ & 17.53 & 0.77 & 69.33 & 9.36 & 2020 & {$[65]$} \\
\hline
\end{tabular}

Table 3 Summary of the key parameters for the solar cells employing MXenes as electrodes

\begin{tabular}{|c|c|c|c|c|c|c|}
\hline Device structure & $J_{\mathrm{sc}}\left(\mathrm{mA} \mathrm{cm}^{-2}\right)$ & $V_{\mathrm{oc}}(\mathrm{V})$ & $\mathrm{FF}(\%)$ & PCE (\%) & Year & References \\
\hline $\mathrm{FTO} / \mathrm{TiO}_{2} / \mathrm{MAPbI}_{3} / \mathrm{Ti}_{3} \mathrm{C}_{2} \mathrm{~T}_{x}$ & 22.96 & 0.95 & 63.00 & 13.83 & 2019 & {$[52]$} \\
\hline $\mathrm{FTO} / \mathrm{c}-\mathrm{TiO}_{2} / \mathrm{CPbBr}_{3} /$ Carbon:CNT: $\mathrm{Ti}_{3} \mathrm{C}_{2} \mathrm{~T}_{x}$ & 7.16 & 1.357 & 72.97 & 7.09 & 2019 & {$[70]$} \\
\hline $\mathrm{Al} / \mathrm{PrC}_{60} \mathrm{MA} / \mathrm{PTB} 7-\mathrm{Th}: \mathrm{PC}_{71} \mathrm{BM} / \mathrm{PEDOT}: \mathrm{PSS} / \mathrm{MXene}-\mathrm{AgNW}-\mathrm{PUA}$ & 14.62 & 0.79 & 61.00 & 7.16 & 2019 & [71] \\
\hline Al/PDINO/PC ${ }_{71}$ BM/PBDB-T: ITIC/PEDOT:PSS/MXene-AgNW-PUA & 13.98 & 0.86 & 64.00 & 7.70 & 2019 & [71] \\
\hline Al/PDINO/PBDB-T:ITIC:PC ${ }_{71}$ BM/PEDOT:PSS/MXene-AgNW-PUA & 14.85 & 0.88 & 63.00 & 8.30 & 2019 & [71] \\
\hline Glass/ $\mathrm{Ti}_{3} \mathrm{C}_{2} \mathrm{~T}_{x} / \mathrm{PEDOT}: \mathrm{PSS} / \mathrm{PM6}$ :Y6/PFN-Br/Al & 24.97 & 0.84 & 64.90 & 13.62 & 2020 & {$[72]$} \\
\hline $\mathrm{Ti}_{3} \mathrm{C}_{2} \mathrm{~T}_{x} / \mathrm{n}^{+}-\mathrm{Si} / \mathrm{n}-\mathrm{Si} / \mathrm{p}^{+}-\mathrm{Si} / \mathrm{Al}_{2} \mathrm{O}_{3} / \mathrm{SiN}_{x} / \mathrm{Ag} / \mathrm{Al}$ & 36.70 & 0.54 & 57.99 & 11.47 & 2019 & {$[73]$} \\
\hline $\mathrm{PDMS} / \mathrm{Au} / \mathrm{Ti}_{3} \mathrm{C}_{2} \mathrm{~T}_{x} / \mathrm{SiO}_{2} / \mathrm{n}-\mathrm{Si} / \mathrm{In}: \mathrm{Ga}$ & 27.21 & 0.574 & 65.00 & 10.22 & 2019 & [74] \\
\hline
\end{tabular}


Table 4 Summary of the key parameters for the solar cells employing MXenes as hole/electron transport layers

\begin{tabular}{|c|c|c|c|c|c|c|}
\hline Device structure & $J_{\mathrm{sc}}\left(\mathrm{mA} \cdot \mathrm{cm}^{-2}\right)$ & $V_{\mathrm{oc}}(\mathrm{V})$ & $\mathrm{FF}(\%)$ & PCE $(\%)$ & Year & References \\
\hline $\mathrm{FTO} / \mathrm{TiO}_{2} / \mathrm{CsPbBr}_{3} / \mathrm{Ti}_{3} \mathrm{C}_{2} \mathrm{~T}_{x} /$ Carbon (HTL) & 8.54 & 1.444 & 73.08 & 9.01 & 2019 & {$[77]$} \\
\hline ITO/U-Ti ${ }_{3} \mathrm{C}_{2} \mathrm{~T}_{x} / \mathrm{PBDB}-\mathrm{T}: \mathrm{ITIC} / \mathrm{Ca} / \mathrm{Al}$ (HTL) & 15.98 & 0.89 & 64.00 & 9.02 & 2019 & {$[53]$} \\
\hline ITO/ $\mathrm{Ti}_{3} \mathrm{C}_{2} \mathrm{~T}_{x} / \mathrm{PBDB}-\mathrm{T}: \mathrm{ITIC} / \mathrm{PFN}-\mathrm{Br} / \mathrm{Al}$ (HTL) & 17.85 & 0.88 & 67.06 & 10.53 & 2019 & {$[80]$} \\
\hline $\mathrm{PDMS} / \mathrm{Au} / \mathrm{Ti}_{3} \mathrm{C}_{2} \mathrm{~T}_{x} / \mathrm{SiO}_{2} / n-\mathrm{Si} / \mathrm{In}: \mathrm{Ga}(\mathrm{HTL})$ & 27.21 & 0.574 & 65.00 & 10.22 & 2019 & [74] \\
\hline ITO/Ti ${ }_{3} \mathrm{C}_{2} \mathrm{~T}_{x} / \mathrm{CH}_{3} \mathrm{NH}_{3} \mathrm{PbI}_{3} /$ Spiro-OMeTAD/Ag (ETL) & 22.63 & 1.08 & 70.00 & 17.17 & 2019 & {$[78]$} \\
\hline FTO/MXene/SnO $2 /$ perovskite/Spiro-OMeTAD/Au (ETL) & 24.34 & 1.11 & 76.40 & 20.65 & 2020 & [79] \\
\hline ITO/UH-Ti ${ }_{3} \mathrm{C}_{2} \mathrm{~T}_{x} / \mathrm{PBDB}-\mathrm{T}: \mathrm{ITIC} / \mathrm{MoO}_{3} / \mathrm{Al}$ (ETL) & 17.36 & 0.87 & 60.00 & 9.06 & 2019 & {$[53]$} \\
\hline
\end{tabular}

different contaminants on $\mathrm{Ti}_{3} \mathrm{C}_{2} \mathrm{~T}_{x}$ and device performance is still lacking. Here, it should also be noted that the previous reports are mainly based on experiments. Accordingly, prediction and optimization of the material properties of MXenes terminated with different functional groups based on theoretical/simulation approaches are necessary for more accurately guiding the experiments [63, 82-84].

On the other hand, the properties of MXenes including morphology, conductivity, transparency, terminating groups, WF and stability are sensitive to the fabrication process. In the meantime, considering the application scenarios, i.e., solar cells, developing the fabrication methods of MXenes with accurately controllable properties, large scale and low cost is necessary [85-87]. Moreover, besides applications in solar cells, other optoelectronic devices such as light-emitting diodes and photodetectors can find more innovations because of the unique optical, electrical and mechanical properties of MXenes. Another issue needing to be concerned is the stability of MXenes if they were exposed to air for a long time due to oxidation, which would increase their resistance and thus reduce the device performance. Thus, appropriate passivation and/or encapsulation is necessary for stable working of the related devices [88-91]. In addition, F-free synthesis of the $\mathrm{Ti}_{3} \mathrm{C}_{2} \mathrm{~T}_{x}$ MXene with high purity has attracted significant attention because of the high safety and environmental friendliness.

There exist more than 100 stoichiometric MXene compositions and a limitless number of solid solutions, which would provide not only unique combinations of properties but also plenty of ways to tune them by changing the ratios of $\mathrm{M}$ or $\mathrm{X}$ elements [92]. To date, only the first discovered MXene, $\mathrm{Ti}_{3} \mathrm{C}_{2} \mathrm{~T}_{x}$, has been applied in the PV field, while other types of MXenes have rarely been reported in application of solar cells. The large underexplored family of MXenes with unique properties make us believe that many exciting discoveries are to come. We optimistically expect that MXenes-based PV devices could achieve a great progress in the near future with further efforts by the researchers in this area.

Based on the above discussion and analysis, several suggestions are given for pushing exploration of MXene's applications in solar cells: (1) deep understanding into the adjustment and optimization of the Fermi level and the electrical properties for $\mathrm{Ti}_{3} \mathrm{C}_{2} \mathrm{~T}_{x}$ MXene materials terminated with varying functional groups based on theoretical prediction and experimental examination for better guiding experimental realization of high-performance solar cells; (2) further improvement of device performance such as PCE and stability based on (1), optimization of each interface in solar cells and incorporation of additional light management structures/components; (3) development of the related flexible PV devices considering the good flexibility of the MXene materials; (4) exploration of novel multifunctional integrated devices such as PV supercapacitors/secondary batteries and self-powered sensors considering the advantages of high transparency, abundant electrochemical active sites and remarkable adjustment of the electrical properties by functional groups for MXenes; and (5) in-depth study of the mechanism of the degraded performance for MXenes in air, exploration of the appropriate passivation and/or encapsulation measures and development of fabrication approaches suitable for solar cell applications. Moreover, besides the further development of the $\mathrm{Ti}_{3} \mathrm{C}_{2} \mathrm{~T}_{x}$ MXene, exploring other suitable MXenes applicable in solar cells is necessary to enrich the related studies and thus to find more opportunities to realize PV devices and/or integrated devices with high performance-to-cost ratios.

Acknowledgements This work was financially supported from the National Natural Science Foundation of China (Grant Nos.: 61376068, 11304132, 11304133 and 61804070) and the Fundamental Research Funds for the Central Universities (Grant Nos.: 
lzujbky-2016-112, lzujbky-2017-178 and lzujbky-2017-181). L. Yin and Y. Li contributed equally to this work.

Open Access This article is licensed under a Creative Commons Attribution 4.0 International License, which permits use, sharing, adaptation, distribution and reproduction in any medium or format, as long as you give appropriate credit to the original author(s) and the source, provide a link to the Creative Commons licence, and indicate if changes were made. The images or other third party material in this article are included in the article's Creative Commons licence, unless indicated otherwise in a credit line to the material. If material is not included in the article's Creative Commons licence and your intended use is not permitted by statutory regulation or exceeds the permitted use, you will need to obtain permission directly from the copyright holder. To view a copy of this licence, visit http://creativecommons.org/licenses/by/4.0/.

\section{References}

1. Y. Wang, P. Shao, Q. Chen, Y. Li, J. Li et al., Nanostructural optimization of silicon/PEDOT: PSS hybrid solar cells for performance improvement. J. Phys. D-Appl. Phys. 50, 175105 (2017). https://doi.org/10.1088/1361-6463/aa64a9

2. A.B. Ren, H.G. Lai, X. Hao, Z.G. Tang, H. Xu et al., Efficient perovskite solar modules with minimized nonradiative recombination and local carrier transport losses. Joule 4, 1263-1277 (2020). https://doi.org/10.1016/j.joule.2020.04.013

3. B. Shi, L. Duan, Y. Zhao, J. Luo, X. Zhang, Semitransparent perovskite solar cells: from materials and devices to applications. Adv. Mater. 32, 1806474 (2020). https://doi. org/10.1002/adma.201806474

4. J. Li, H. Yu, S. Wong, X. Li, G. Zhang et al., Design guidelines of periodic Si nanowire arrays for solar cell application. Appl. Phys. Lett. 95, 3 (2009). https://doi.org/10.1063/1.3275798

5. X. Ma, Y. Mi, F. Zhang, Q. An, M. Zhang et al., Efficient ternary polymer solar cells with two well-compatible donors and one ultranarrow bandgap nonfullerene acceptor. Adv. Energy Mater. 8, 1702854 (2018). https://doi.org/10.1002/aenm.20170 2854

6. D. Zhao, C. Zhang, H. Kim, L.J. Guo, High-performance $\mathrm{Ta}_{2} \mathrm{O}_{5} / \mathrm{Al}$-doped $\mathrm{Ag}$ electrode for resonant light harvesting in efficient organic solar cells. Adv. Energy Mater. 5, 1500768 (2015). https://doi.org/10.1002/aenm.201500768

7. Y. Li, J. Li, H. Yu, S.-M. Wong, X. Sun et al., Novel silicon nanohemisphere-array solar cells with enhanced performance. Small 7, 3138-3143 (2011). https://doi.org/10.1002/ smll.201100950

8. S. Zhang, Y. Qin, J. Zhu, J. Hou, Over $14 \%$ efficiency in polymer solar cells enabled by a chlorinated polymer donor. Adv. Mater. 30, 1800868 (2018). https://doi.org/10.1002/ adma.201800868

9. Z. Wan, H. Lai, S. Ren, R. He, Y. Jiang et al., Interfacial engineering in lead-free tin-based perovskite solar cells. J. Energy Chem. 57, 147-168 (2020). https://doi.org/10.1016/j.jeche m.2020.08.053
10. Y. Zhao, X. Han, L. Chang, C. Dong, J. Li et al., Effects of selenization conditions on microstructure evolution in solution processed $\mathrm{Cu}_{2} \mathrm{ZnSn}(\mathrm{S}, \mathrm{Se})_{4}$ solar cells. Sol. Energy Mater. Sol. Cells 195, 274-279 (2019). https://doi.org/10.1016/j.solma t.2019.03.024

11. A.B. Ren, J.H. Zou, H.G. Lai, Y.X. Huang, L.M. Yuan et al., Direct laser-patterned MXene-perovskite image sensor arrays for visible-near infrared photodetection. Mater. Horizons 7, 1901-1911 (2020). https://doi.org/10.1039/d0mh00537a

12. J. Li, H. Yu, Y. Li, F. Wang, M. Yang et al., Low aspect-ratio hemispherical nanopit surface texturing for enhancing light absorption in crystalline Si thin film-based solar cells. Appl. Phys. Lett. 98, 3 (2011). https://doi.org/10.1063/1.3537810

13. D. Zhao, L. Ding, All-perovskite tandem structures shed light on thin-film photovoltaics. Sci. Bull. 65, 1144-1146 (2020). https://doi.org/10.1016/j.scib.2020.04.013

14. J. Li, H. Yu, Y. Li, Aligned Si nanowire-based solar cells. Nanoscale 3, 4888-4900 (2011). https://doi.org/10.1039/c1nr1 $0943 \mathrm{j}$

15. M. Naguib, M. Kurtoglu, V. Presser, J. Lu, J. Niu et al., Twodimensional nanocrystals produced by exfoliation of $\mathrm{Ti}_{3} \mathrm{AlC}_{2}$. Adv. Mater. 23, 4248-4253 (2011). https://doi.org/10.1002/ adma.201102306

16. M.Q. Zhao, C.E. Ren, Z. Ling, M.R. Lukatskaya, C. Zhang et al., Flexible MXene/carbon nanotube composite paper with high volumetric capacitance. Adv. Mater. 27, 339-345 (2015). https://doi.org/10.1002/adma.201404140

17. J. Pang, R.G. Mendes, A. Bachmatiuk, L. Zhao et al., Applications of 2D MXenes in energy conversion and storage systems. Chem. Soc. Rev. 48, 72-133 (2019). https://doi. org/10.1039/c8cs00324f

18. L. Jia, Y. Li, L. Su, D. Liu, Y. Fu et al., $\mathrm{TiO}_{2}$ nanoparticles in situ formed on $\mathrm{Ti}_{3} \mathrm{C}_{2}$ nanosheets by a one-step ethanolthermal method for enhanced reversible lithium-ion storage. ChemistrySelect 5, 3124-3129 (2020). https://doi. org/10.1002/slct.202000521

19. X. Zang, J. Wang, Y. Qin, T. Wang, C. He et al., Enhancing capacitance performance of $\mathrm{Ti}_{3} \mathrm{C}_{2} \mathrm{~T}_{x}$ MXene as electrode materials of supercapacitor: from controlled preparation to composite structure construction. Nano-Micro Lett. 12, 77 (2020). https://doi.org/10.1007/s40820-020-0415-5

20. H. Jiang, Z. Wang, Q. Yang, L. Tan, L. Dong et al., Ultrathin $\mathrm{Ti}_{3} \mathrm{C}_{2} \mathrm{~T}_{x}$ (MXene) nanosheet-wrapped $\mathrm{NiSe}_{2}$ octahedral crystal for enhanced supercapacitor performance and synergetic electrocatalytic water splitting. Nano-Micro Lett. 11, 31 (2019). https://doi.org/10.1007/s40820-019-0261-5

21. H. Liu, X. Zhang, Y. Zhu, B. Cao, Q. Zhu et al., Electrostatic self-assembly of 0D-2D $\mathrm{SnO}_{2}$ quantum dots/ $\mathrm{Ti}_{3} \mathrm{C}_{2} \mathrm{~T}_{x}$ MXene hybrids as anode for lithium-ion batteries. Nano-Micro Lett. 11, 65 (2019). https://doi.org/10.1007/s40820-019-0296-7

22. S. Zhang, H. Ying, B. Yuan, R. Hu, W.-Q. Han, Partial atomic tin nanocomplex pillared few-layered $\mathrm{Ti}_{3} \mathrm{C}_{2} \mathrm{~T}_{x}$ MXenes for superior lithium-ion storage. Nano-Micro Lett. 12, 78 (2020). https://doi.org/10.1007/s40820-020-0405-7

23. Y. Ma, Y. Yue, H. Zhang, F. Cheng, W. Zhao et al., 3D synergistical MXene/reduced graphene oxide aerogel for 
a piezoresistive sensor. ACS Nano 12, 3209-3216 (2018). https://doi.org/10.1021/acsnano.7b06909

24. P.K. Kalambate, N.S. Gadhari, X. Li, Z. Rao, S.T. Navale et al., Recent advances in MXene-based electrochemical sensors and biosensors. TrAC Trends Anal. Chem. 120, 115643 (2019). https://doi.org/10.1016/j.trac.2019.115643

25. Y.J. Lei, E.N. Zhao, Y.Z. Zhang, Q. Jiang, J.H. He et al., A MXene-based wearable biosensor system for high-performance in vitro perspiration analysis. Small 15, 1901190 (2019). https://doi.org/10.1002/smll.201901190

26. S. Zhao, H.-B. Zhang, J.-Q. Luo, Q.-W. Wang, B. Xu et al., Highly electrically conductive three-dimensional $\mathrm{Ti}_{3} \mathrm{C}_{2} \mathrm{~T}_{x}$ MXene/reduced graphene oxide hybrid aerogels with excellent electromagnetic interference shielding performances. ACS Nano 12, 11193-11202 (2018). https://doi. org/10.1021/acsnano.8b05739

27. A. Iqbal, P. Sambyal, C.M. Koo, 2D MXenes for electromagnetic shielding: a review. Adv. Funct. Mater. (2020). https:// doi.org/10.1002/adfm.202000883

28. B. Deng, Z. Xiang, J. Xiong, Z. Liu, L. Yu et al., Sandwichlike $\mathrm{Fe} \& \mathrm{TiO}_{2} @ \mathrm{C}$ nanocomposites derived from MXene/ Fe-MOFs hybrids for electromagnetic absorption. NanoMicro Lett. 12, 55 (2020). https://doi.org/10.1007/s4082 0-020-0398-2

29. W. Cao, C. Ma, S. Tan, M. Ma, P. Wan et al., Ultrathin and flexible CNTs/MXene/cellulose nanofibrils composite paper for electromagnetic interference shielding. Nano-Micro Lett. 11, 72 (2019). https://doi.org/10.1007/s40820-019-0304-y

30. Y. Cai, J. Shen, G. Ge, Y. Zhang, W. Jin et al., Stretchable $\mathrm{Ti}_{3} \mathrm{C}_{2} \mathrm{~T}_{x}$ MXene/carbon nanotube composite based strain sensor with ultrahigh sensitivity and tunable sensing range. ACS Nano 12, 56-62 (2018). https://doi.org/10.1021/acsna no.7b06251

31. S.J. Kim, H.-J. Koh, C.E. Ren, O. Kwon, K. Maleski et al., Metallic $\mathrm{Ti}_{3} \mathrm{C}_{2} \mathrm{~T}_{x}$ MXene gas sensors with ultrahigh signalto-noise ratio. ACS Nano 12, 986-993 (2018). https://doi. org/10.1021/acsnano.7b07460

32. S.Y. Li, Y. Zhang, W. Yang, H. Liu, X.S. Fang, 2D perovskite $\mathrm{Sr}_{2} \mathrm{Nb}_{3} \mathrm{O}_{10}$ for high-performance UV photodetectors. Adv. Mater. 32, 1905443 (2020). https://doi.org/10.1002/ adma.201905443

33. J.X. Chen, Z.L. Li, F.L. Ni, W.X. Ouyang, X.S. Fang, Bioinspired transparent MXene electrodes for flexible UV photodetectors. Mater. Horizons 7, 1828-1833 (2020). https://doi. org/10.1039/d0mh00394h

34. W.X. Ouyang, J.X. Chen, J.H. He, X.S. Fang, Improved photoelectric performance of UV photodetector based on $\mathrm{ZnO}$ nanoparticle-decorated biocl nanosheet arrays onto PDMS substrate: the heterojunction and $\mathrm{Ti}_{3} \mathrm{C}_{2} \mathrm{~T}_{x}$ MXene conduction layer. Adv. Electron. Mater. 6, 2000168 (2020). https://doi. org/10.1002/aelm.202000168

35. Q. Xu, W.J. Yang, Y.Y. Wen, S.K. Liu, Z. Liu et al., Hydrochromic full-color MXene quantum dots through hydrogen bonding toward ultrahigh-efficiency white light-emitting diodes. Appl. Mater. Today 16, 90-101 (2019). https://doi. org/10.1016/j.apmt.2019.05.001
36. S. Ahn, T.H. Han, K. Maleski, J. Song, Y.H. Kim et al., A 2D titanium carbide MXene flexible electrode for high-efficiency light-emitting diodes. Adv. Mater. 32, 2000919 (2020). https ://doi.org/10.1002/adma.202000919

37. S. Lee, E.H. Kim, S. Yu, H. Kim, C. Park et al., Alternating-current MXene polymer light-emitting diodes. Adv. Funct. Mater. 30, 2001224 (2020). https://doi.org/10.1002/ adfm.202001224

38. I. Ihsanullah, Potential of MXenes in water desalination: current status and perspectives. Nano-Micro Lett. 12, 72 (2020). https://doi.org/10.1007/s40820-020-0411-9

39. Q.R. Zhang, J. Teng, G.D. Zou, Q.M. Peng, Q. Du et al., Efficient phosphate sequestration for water purification by unique sandwich-like MXene/magnetic iron oxide nanocomposites. Nanoscale 8, 7085-7093 (2016). https://doi.org/10.1039/c5nr0 9303a

40. X.Q. Xie, C. Chen, N. Zhang, Z.R. Tang, J.J. Jiang et al., Microstructure and surface control of MXene films for water purification. Nat. Sustain. 2, 856-862 (2019). https://doi. org/10.1038/s41893-019-0373-4

41. Y. Lu, D.Q. Fan, H.L. Xu, H.H. Min, C.H. Lu et al., Implementing hybrid energy harvesting in 3D spherical evaporator for solar steam generation and synergic water purification. Solar RRL 4, 2000232 (2020). https://doi.org/10.1002/ solr.202000232

42. X. Wu, M. Ding, H. Xu, W. Yang, K. Zhang et al., Scalable $\mathrm{Ti}_{3} \mathrm{C}_{2} \mathrm{~T}_{x}$ MXene interlayered forward osmosis membranes for enhanced water purification and organic solvent recovery. ACS Nano 14, 9125-9135 (2020). https://doi.org/10.1021/ acsnano.0c04471

43. X. Ming, A. Guo, Q. Zhang, Z. Guo, F. Yu et al., 3D macroscopic graphene oxide/MXene architectures for multifunctional water purification. Carbon 167, 285-295 (2020). https ://doi.org/10.1016/j.carbon.2020.06.023

44. Z.L. Li, Z.C. Zhuang, F. Lv, H. Zhu, L. Zhou et al., The marriage of the $\mathrm{FeN}_{4}$ moiety and MXene boosts oxygen reduction catalysis: $\mathrm{Fe} 3 \mathrm{~d}$ electron delocalization matters. Adv. Mater. 30, 1803220 (2018). https://doi.org/10.1002/ adma. 201803220

45. B. Ahmed, A.E. Ghazaly, J. Rosen, $i$-MXenes for energy storage and catalysis. Adv. Funct. Mater. 30, 2000894 (2020). https://doi.org/10.1002/adfm.202000894

46. J. Wang, Z. Zhang, X. Yan, S. Zhang, Z. Wu et al., Rational design of porous $\mathrm{N}-\mathrm{Ti}_{3} \mathrm{C}_{2}$ MXene@CNT microspheres for high cycling stability Li-S battery. Nano-Micro Lett. 12, 4 (2020). https://doi.org/10.1007/s40820-019-0341-6

47. Y.L. Sun, X. Meng, Y. Dall'Agnese, C. Dall'Agnese, S.N. Duan et al., 2D MXenes as co-catalysts in photocatalysis: synthetic methods. Nano-Micro Lett. 11, 79 (2019). https:// doi.org/10.1007/s40820-019-0309-6

48. M. Xu, S. Lei, J. Qi, Q. Dou, L. Liu et al., Opening magnesium storage capability of two-dimensional MXene by intercalation of cationic surfactant. ACS Nano 12, 3733-3740 (2018). https ://doi.org/10.1021/acsnano.8b00959

49. M. Khazaei, A. Ranjbar, M. Arai, T. Sasaki, S. Yunoki, Electronic properties and applications of MXenes: a theoretical 
review. J. Mater. Chem. C 5, 2488-2503 (2017). https://doi. org/10.1039/c7tc00140a

50. M. Shi, P. Xiao, J. Lang, C. Yan, X. Yan, Porous $g-\mathrm{C}_{3} \mathrm{~N}_{4}$ and MXene dual-confined $\mathrm{FeOOH}$ quantum dots for superior energy storage in an ionic liquid. Adv. Sci. 7, 1901975 (2020). https://doi.org/10.1002/advs.201901975

51. Z. Guo, L. Gao, Z. Xu, S. Teo, C. Zhang et al., High electrical conductivity 2D MXene serves as additive of perovskite for efficient solar cells. Small 14, 1802738 (2018). https://doi. org/10.1002/smll.201802738

52. J. Cao, F. Meng, L. Gao, S. Yang, Y. Yan et al., Alternative electrodes for HTMs and noble-metal-free perovskite solar cells: 2D MXenes electrodes. RSC Adv. 9, 34152-34157 (2019). https://doi.org/10.1039/c9ra06091j

53. Z. Yu, W. Feng, W. Lu, B. Li, H. Yao et al., MXenes with tunable work functions and their application as electronand hole-transport materials in non-fullerene organic solar cells. J. Mater. Chem. A 7, 11160-11169 (2019). https://doi. org/10.1039/c9ta01195a

54. Z. Wu, Y. Wang, Y. Zhang, W. Zhang, Q. Liu et al., Enhanced performance of polymer solar cells by adding $\mathrm{SnO}_{2}$ nanoparticles in the photoactive layer. Org. Electron. 73, 7-12 (2019). https://doi.org/10.1016/j.orgel.2019.05.038

55. Z. Wu, W. Zhang, C. Xie, L. Zhang, Y. Wang et al., Bridging for carriers by embedding metal oxide nanoparticles in the photoactive layer to enhance performance of polymer solar cells. IEEE J. Photovolt. 10, 1353-1358 (2020). https://doi. org/10.1109/JPHOTOV.2020.3004926

56. Y. Wang, Y. Zhang, L. Zhang, Z. Wu, Q. Su et al., Enhanced performance and the related mechanisms of organic solar cells using Li-doped $\mathrm{SnO}_{2}$ as the electron transport layer. Mater. Chem. Phys. 254, 123536 (2020). https://doi. org/10.1016/j.matchemphys.2020.123536

57. P. Shao, X. Chen, X. Guo, W. Zhang, F. Chang et al., Facile embedding of $\mathrm{SiO}_{2}$ nanoparticles in organic solar cells for performance improvement. Org. Electron. 50, 77-81 (2017). https://doi.org/10.1016/j.orgel.2017.07.029

58. A. Agresti, A. Pazniak, S. Pescetelli, A. Di Vito, D. Rossi et al., Titanium-carbide MXenes for work function and interface engineering in perovskite solar cells. Nat. Mater. 18, 1228-1234 (2019). https://doi.org/10.1038/s4156 3-019-0527-9

59. Z. Zhang, Y. Li, C. Liang, G. Yu, J. Zhao et al., In situ growth of $\mathrm{MAPbBr}_{3}$ nanocrystals on few-layer MXene nanosheets with efficient energy transfer. Small 16, 1905896 (2020). https://doi.org/10.1002/smll.201905896

60. X. Chen, W. Xu, N. Ding, Y. Ji, G. Pan et al., Dual interfacial modification engineering with 2D MXene quantum dots and copper sulphide nanocrystals enabled high-performance perovskite solar cells. Adv. Funct. Mater. 30, 2003295 (2020). https://doi.org/10.1002/adfm.202003295

61. L. Yang, Y. Dall'Agnese, K. Hantanasirisakul, C.E. Shuck, $\mathrm{K}$. Maleski et al., $\mathrm{SnO}_{2}-\mathrm{Ti}_{3} \mathrm{C}_{2} \mathrm{MXene}$ electron transport layers for perovskite solar cells. J. Mater. Chem. A 7, 56355642 (2019). https://doi.org/10.1039/c8ta12140k
62. L. Huang, X. Zhou, R. Xue, P. Xu, S. Wang et al., Lowtemperature growing anatase $\mathrm{TiO}_{2} / \mathrm{SnO}_{2}$ multi-dimensional heterojunctions at MXene conductive network for high-efficient perovskite solar cells. Nano-Micro Lett. 12, 44 (2020). https://doi.org/10.1007/s40820-020-0379-5

63. A. Di Vito, A. Pecchia, M. Auf der Maur, A. Di Carlo, Nonlinear work function tuning of lead-halide perovskites by MXenes with mixed terminations. Adv. Funct Mater. 30, 1909028 (2020). https://doi.org/10.1002/adfm.201909028

64. C. Hou, H. Yu, Modifying the nanostructures of PEDOT: $\mathrm{PSS} / \mathrm{Ti}_{3} \mathrm{C}_{2} \mathrm{~T}_{x}$ composite hole transport layers for highly efficient polymer solar cells. J. Mater. Chem. C 8, 4169-4180 (2020). https://doi.org/10.1039/d0tc00075b

65. C. Hou, H. Yu, $\mathrm{Zno} / \mathrm{Ti}_{3} \mathrm{C}_{2} \mathrm{~T}_{x}$ monolayer electron transport layers with enhanced conductivity for highly efficient inverted polymer solar cells. Chem. Eng. J. (2020). https:// doi.org/10.1016/j.cej.2020.127192

66. J. Zhang, N. Kong, S. Uzun, A. Levitt, S. Seyedin et al., Scalable manufacturing of free-standing, strong $\mathrm{Ti}_{3} \mathrm{C}_{2} \mathrm{~T}_{x}$ MXene films with outstanding conductivity. Adv. Mater. 32, 2001093 (2020). https://doi.org/10.1002/adma.202001093

67. K. Hantanasirisakul, Y. Gogotsi, Electronic and optical properties of $2 \mathrm{D}$ transition metal carbides and nitrides (MXenes). Adv. Mater. 30, 1804779 (2018). https://doi. org/10.1002/adma.201804779

68. D. Xiong, X. Li, Z. Bai, S. Lu, Recent advances in layered $\mathrm{Ti}_{3} \mathrm{C}_{2} \mathrm{~T}_{x}$ MXene for electrochemical energy storage. Small 14, 1703419 (2018). https://doi.org/10.1002/smll.20170 3419

69. K. Li, M. Liang, H. Wang, X. Wang, Y. Huang et al., 3D MXene architectures for efficient energy storage and conversion. Adv. Funct. Mater. 30, 2000842 (2020). https://doi. org/10.1002/adfm.202000842

70. L. Mi, Y. Zhang, T. Chen, E. Xu, Y. Jiang, Carbon electrode engineering for high efficiency all-inorganic perovskite solar cells. RSC Adv. 10, 12298-12303 (2020). https://doi. org/10.1039/d0ra00288g

71. H. Tang, H. Feng, H. Wang, X. Wan, J. Liang et al., Highly conducting MXene-silver nanowire transparent electrodes for flexible organic solar cells. ACS Appl. Mater. Interfaces 11, 25330-25337 (2019). https://doi.org/10.1021/acsami.9b04113

72. L. Qin, J. Jiang, Q. Tao, C. Wang, I. Persson et al., A flexible semitransparent photovoltaic supercapacitor based on waterprocessed MXene electrodes. J. Mater. Chem. A 8, 5467-5475 (2020). https://doi.org/10.1039/d0ta00687d

73. H.C. Fu, V. Ramalingam, H. Kim, C.H. Lin, X. Fang et al., MXene-contacted silicon solar cells with $11.5 \%$ efficiency. Adv. Energy Mater. 9, 1900180 (2019). https://doi. org/10.1002/aenm.201900180

74. L. Yu, A.S. Bati, T.S. Grace, M. Batmunkh, J.G. Shapter, $\mathrm{Ti}_{3} \mathrm{C}_{2} \mathrm{~T}_{x}$ (MXene)-silicon heterojunction for efficient photovoltaic cells. Adv. Energy Mater. 9, 1901063 (2019). https:// doi.org/10.1002/aenm.201901063

75. Y. Chen, D. Wang, Y. Lin, X. Zou, T. Xie, In suit growth of $\mathrm{CuSe}$ nanoparticles on MXene $\left(\mathrm{Ti}_{3} \mathrm{C}_{2}\right)$ nanosheets as an 
efficient counter electrode for quantum dot-sensitized solar cells. Electrochim. Acta 316, 248-256 (2019). https://doi. org/10.1016/j.electacta.2019.05.132

76. Z. Tian, Z. Qi, Y. Yang, H. Yan, Q. Chen et al., Anchoring CuS nanoparticles on accordion-like $\mathrm{Ti}_{3} \mathrm{C}_{2}$ as high electrocatalytic activity counter electrodes for QDSSCs. Inorg. Chem. Front. 7, 3727-3734 (2020). https://doi.org/10.1039/d0qi00618a

77. T. Chen, G. Tong, E. Xu, H. Li, P. Li et al., Accelerating hole extraction by inserting $2 \mathrm{D} \mathrm{Ti}_{3} \mathrm{C}_{2}$-MXene interlayer to all inorganic perovskite solar cells with long-term stability. J. Mater. Chem. A 7, 20597-20603 (2019). https://doi.org/10.1039/ c9ta06035a

78. L. Yang, C. Dall'Agnese, Y. Dall'Agnese, G. Chen, Y. Gao et al., Surface-modified metallic $\mathrm{Ti}_{3} \mathrm{C}_{2} \mathrm{~T}_{x}$ MXene as electron transport layer for planar heterojunction perovskite solar cells. Adv. Funct. Mater. 29, 1905694 (2019). https://doi. org/10.1002/adfm.201905694

79. Y. Wang, P. Xiang, A. Ren, H. Lai, Z. Zhang et al., MXenemodulated electrode $/ \mathrm{SnO}_{2}$ interface boosting charge transport in perovskite solar cells. ACS Appl. Mater. Interfaces 12, 53973-53983 (2020). https://doi.org/10.1021/acsami.0c17338

80. C. Hou, H. Yu, C. Huang, Solution-processable $\mathrm{Ti}_{3} \mathrm{C}_{2} \mathrm{~T}_{x}$ nanosheets as an efficient hole transport layer for high-performance and stable polymer solar cells. J. Mater. Chem. C 7, 11549-11558 (2019). https://doi.org/10.1039/c9tc03415c

81. Y. Li, J. Wang, W. Zhang, Q. Liu, Q. Chen et al., A simple and efficient device configuration applicable in high-performance solar cells with limited material requirements. J. Phys. D: Appl. Phys. 52, 435501 (2019). https://doi.org/10.1088/13616463/ab35ac

82. L. Zhou, Y. Zhang, Z. Zhuo, A.J. Neukirch, S. Tretiak, Interlayer-decoupled Sc-based MXene with high carrier mobility and strong light-harvesting ability. J. Phys. Chem. Lett. 9, 6915-6920 (2018). https://doi.org/10.1021/acs.jpclett.8b030 77

83. X. Chen, J. Wang, S. Qin, Q. Chen, Y. Li et al., Wedgeshaped semiconductor nanowall arrays with excellent light management. Opt. Lett. 42, 3928-3931 (2017). https://doi. org/10.1364/OL.42.003928
84. Y. Zhang, R. Xiong, B. Sa, J. Zhou, Z. Sun, MXenes: Promising donor and acceptor materials for high-efficiency heterostructure solar cells. Sustain. Energy Fuels 5, 135-143 (2021). https://doi.org/10.1039/D0SE01443E

85. A. Iqbal, F. Shahzad, K. Hantanasirisakul, M.K. Kim, J. Kwon et al., Anomalous absorption of electromagnetic waves by $2 \mathrm{D}$ transition metal carbonitride $\mathrm{Ti}_{3} \mathrm{CNT}_{x}$ (MXene). Science 369, 446-450 (2020). https://doi.org/10.1126/science.aba7977

86. S.L. Zhang, P.F. Huang, J.L. Wang, Z.H. Zhuang, Z. Zhang et al., Fast and universal solution-phase flocculation strategy for scalable synthesis of various few-layered MXene powders. J. Phys. Chem. Lett. 11, 1247-1254 (2020). https://doi. org/10.1021/acs.jpclett.9b03682

87. C.E. Shuck, A. Sarycheva, M. Anayee, A. Levitt, Y.Z. Zhu et al., Scalable synthesis of $\mathrm{Ti}_{3} \mathrm{C}_{2} \mathrm{~T}_{x}$ MXene. Adv. Eng. Mater. 22, 1901241 (2020). https://doi.org/10.1002/adem.201901241

88. V. Natu, J.L. Hart, M. Sokol, H. Chiang, M.L. Taheri et al., Edge capping of 2D-MXene sheets with polyanionic salts to mitigate oxidation in aqueous colloidal suspensions. Angew. Chem. Int. Ed. 58, 12655-12660 (2019). https://doi. org/10.1002/anie.201906138

89. C.W. Wu, B. Unnikrishnan, I.W.P. Chen, S.G. Harroun, H.T. Chang et al., Excellent oxidation resistive MXene aqueous ink for micro-supercapacitor application. Energy Storage Mater. 25, 563-571 (2020). https://doi.org/10.1016/j. ensm.2019.09.026

90. J.J. Ji, L.F. Zhao, Y.F. Shen, S.Q. Liu, Y.J. Zhang, Covalent stabilization and functionalization of MXene via silylation reactions with improved surface properties. Flatchem 17, 100128 (2019). https://doi.org/10.1016/j.flatc.2019.100128

91. Y. Lee, S.J. Kim, Y.J. Kim, Y. Lim, Y. Chae et al., Oxidationresistant titanium carbide MXene films. J. Mater. Chem. A 8, 573-581 (2020). https://doi.org/10.1039/c9ta07036b

92. Y. Gogotsi, B. Anasori, The rise of MXenes. ACS Nano 13, 8491-8494 (2019). https://doi.org/10.1021/acsnano.9b06394 